Volume 102

Issue 2 Dickinson Law Review - Volume 102,

1997-1998

$1-1-1998$

\title{
Go to the Mall with My Parents?? A Constitutional Analysis of the Mall of America's Juvenile Curfew
}

Alysa B. Freeman

Follow this and additional works at: https://ideas.dickinsonlaw.psu.edu/dlra

\section{Recommended Citation}

Alysa B. Freeman, Go to the Mall with My Parents?? A Constitutional Analysis of the Mall of America's Juvenile Curfew, 102 Dick. L. Rev. 481 (1998).

Available at: https://ideas.dickinsonlaw.psu.edu/dlra/vol102/iss2/13

This Comment is brought to you for free and open access by the Law Reviews at Dickinson Law IDEAS. It has been accepted for inclusion in Dickinson Law Review by an authorized editor of Dickinson Law IDEAS. For more information, please contactlja10@psu.edu. 


\section{Go to the Mall with My Parents?? A Constitutional Analysis of the Mall of America's Juvenile Curfew*}

\section{Introduction}

The Mall of America (the "Mall"), located in Bloomington, Minnesota, could only exist in the United States. With 4.2 million square feet of gross building area, ${ }^{1}$ it is the largest retail and entertainment center in the country. ${ }^{2}$ Since its opening on August 11, 1992, the Mall has become a tremendous tourist magnet for Americans and foreign visitors alike. ${ }^{3}$ The Mall is a living, breathing monument to American consumerism and to the collective fulfilled desire for a shopping experience that is as convenient, all-encompassing, and as efficient as possible. Convenient is certainly the operative word as the Mall contains infant care facilities, a high school, a college, a United States Post Office, a

* Author's note: Shortly before this comment was published, a decision from the Minnesota Court of Appeals, adverse to the central thesis of this comment, was handed down. See Minnesota v. Wicklund, No. C7-97-1381, 1998 WL 156240 (Minn. Ct. App. Apr. $7,1998)$. The court of appeals, reversing the trial court, held that the free speech provision of article I, section 3 of the Minnesota Constitution does not apply to the Mall of America. Nevertheless, this comment argues for an expansion of the state's protections of individual liberties under article I, section 16 of the Minnesota Constitution.

1. See Public Relations Dep't, Mall of America, At a Glance (1996) [hereinafter AT A GLANCE]. Unless otherwise stated, all of the Mall's promotional materials, as well as two 1996 press releases, are based on promotional material provided by the Mall of America. The promotional material consisted of nine glossy $81 / 2 \times 11^{\prime \prime}$ sheets that detailed the Mall's variety of offerings (i.e. "Tourism" and "Restaurants \& Nightclubs"); three brochures: "Map and Directory," "Dining and Entertainment Guide," and "The Place for Fun in Your Life;" and two press releases dated September 4, 1996 and October 8, 1996. The information packet was requested in early October 1996 and was received on October 11, 1996. An updated information package was received on October 20, 1997, and references to the 1997 information are noted herein.

2. See Public Relations Dep'T, Mall of america, Destination Planning Guide, 1997-1998, 2 (1997) [hereinafter Destination PLANNING GUIDE].

3. Over 190 million people have been to the Mall since its opening. See AT A GLANCE, supra note 1. Visitors from outside a 150 mile radius account for greater than $30 \%$ of the Mall's visitors. See id. International visitors account for $6 \%$. See PUBLIC RELATIONS DEP'T, MALl OF AMERICA, TourISM (1996) [hereinafter TOURISM]; AT A GlanCE, supra note 1 . 
bank, a hotel, a dental clinic, and a myriad of other non-shopping services. $^{4}$ Not only do the 520 shopping stores ${ }^{5}$ under one roof provide for an efficient one-stop shopping experience, but the Mall has other types of attractions-including entertainment and dining-for practically every taste. ${ }^{6}$

Not surprisingly, teenagers frequent the Mall of America. Like their counterparts around the country, Minnesota teens regularly go to the Mall on weekend evenings. Estimates hold that between two and three thousand teenagers frequent the Mall of America on both Friday and Saturday evenings. ${ }^{7}$ Many, if not most, go to the Mall because there is little else to do in the community on weekend evenings and because the Mall is a good place to see and be seen. ${ }^{8}$ Due to its size, the Mall is thus faced with a proportionately larger group of teen visitors than are other malls across the nation.

Mall of America management initiated a number of creative solutions to handle teen conduct-related issues. ${ }^{9}$ However, after

4. See Public Relations Dep'T, Mall of America, Map and Directory (1996) [hereinafter MAP AND DIRECTORY]; DESTINATION PLANNING GuIDE, supra note 2. For a detailed discussion of the services the Mall offers its visitors, see infra text accompanying notes 107-13.

5. See AT A GlanCE, supra note 1.

6. Youth entertainment includes Knott's Camp Snoopy, LEGO Imagination Center, and StarBase Omega. See Public Relations DeP'T, Mall of America, Family Fun (1996) [hereinafter FAMILY FUN]. For further information on these amusements, as well as adult and family-oriented attractions, see infra text accompanying notes 97, 115-19.

7. See Robyn Meredith, Big Mall's Curfew Raises Questions of Rights and Bias, N.Y. Times, Sept. 4, 1996, at A1.

The importance of teen spending in United States commerce is evidenced by the fact that teenage spending in the United States is estimated at over $\$ 100$ billion. See Leyla Kokmen, Hang Time-Mall of America Withdraws Welcome Mat to Teens Who Gather on Weekends, CHI. TRIB., Sept. 15, 1996 (citing a study conducted by Teenage Research Unlimited). See also Chuck Haga, Minnesota Megamall's Effort to Subdue Teen Rowdiness Raises Issues of Fairness and Racial Bias, THE CHRISTIAN SCI. MONITOR, Oct. 9, 1996.

8. See Meredith, supra note 7, at B9.

9. The Mall instituted a Youth Liaison Program in January 1995. See Public Relations Dep't, Mall of America, Press Release (Sept. 4, 1996) [hereinafter September Press Release]. In this program, security officers work with teens both inside and outside the Mall. See id. The officers are casually dressed when they visit schools to discuss appropriate behavior at the Mall. See id. They also volunteer at youth community organizations. See id. In April 1996, the Mall instituted the Mighty Moms Program. See id. It consists of twenty women who work with security officers in handling conflicts between disruptive teenagers and Mall security. See Neal Karlen, Tapping 'Mom Power' to Police a Huge Mall, N.Y. TImes, Dec. 19, 1996, at C2. The Mighty Moms are able to diffuse tense situations and are highly effective at combating ugly confrontations between mall security and teens. See id. The Mall has also hired ten Dedicated Dads to serve the same function. For a further discussion of 
a small eruption of gun violence in which teens were both the perpetrators and the victims ${ }^{10}$ Mall management initiated more drastic measures. Thus, on October 4, 1996, the privately-owned Mall $^{11}$ instituted a juvenile curfew termed a Parental Escort Policy; the goal of this policy was to reduce the number of unaccompanied teenagers at the Mall on weekend nights. ${ }^{12}$ Under the policy, guards are posted at the Mall's twenty-three entrances and deny access after 6 p.m. on Friday and Saturday nights to anyone who is under the age of sixteen and not in the company of an adult twenty-one years of age or older. ${ }^{13}$ The adult must exercise control over the teens in his or her care. ${ }^{14}$ Mall security has the discretion to decide whether the group of teens is too large to be controlled by its escort. ${ }^{15}$ The Mall's management states that it instituted the curfew as a preventative measure in order to

these Mall programs, see infra text accompanying notes 176-78.

10. In June 1996, Nancy A. Bordeaux and her family were visiting the Mall when a teenager pointed his gun at her sixteen year old son Felix. See Meredith, supra note 7, at B9. The gun-toting youth mistakenly thought Felix was a member of a rival group that he was chasing through the Mall. See id.

A widely reported incident occurred in 1993 in the Camp Snoopy Amusement Park. One group of male teenagers approached another group and demanded that a thirteen year old boy in the second group give them his jacket. See Bob Greene, What to Do When Trouble Shows Up? Easy, Call Mom, CHI. TRIB., May 7, 1996. There was a gunfight and three of the teenagers were shot. See id. These are the two most widely news reported incidences of gun violence.

11. The owners of the Mall are Triple Five Corp., Melvin Simon \& Assoc., and the Teacher's Insurance \& Annuity Ass'n. See AT A GLANCE, supra note 1.

12. See September Press Release, supra note 9. "Mall of America will implement a Parental Escort Policy effective October 4, 1996, to reduce the growing number of unsupervised youth at the Mall on weekend nights." Id.

13. See id. Mall security will also conduct sweeps throughout the Mall between 6 p.m. and closing to ask for identification from teenagers who entered the Mall prior to 6 p.m. See id.

14. One adult may escort up to 10 children ages 15 and younger. See DeSTINATION PLANNING GUIDE, supra note 2.

When teenagers throughout the country were surveyed by various newspapers regarding their thoughts on the Mall's juvenile curfew, the overwhelming majority felt that the curfew was unfair and too restrictive. One Minnesota teen's response to the Parental Escort Policy was succinct: "[I]t would stink. If you came here with your mom, you'd have to go to Linens 'N Things. And you wouldn't have any independence." Sally Apgar, Escort Policy for Youths Considered by Megamall, MINnEAPOLIS-ST. PAUl STAR-TRIB., June 20, 1996. Added another teen, "[T]

"Teen-age shoppers who were interviewed recently said they would not be caught dead with their parents at the Mall of America, the biggest mall in the country and the coolest spot in town." Meredith, supra note 7, at A1.

15. See September Press Release, supra note 9. 
avoid future teen violence. ${ }^{16}$ Mall management was further concerned for the safety of innocent bystanders, as it desires to maintain a safe atmosphere for all who patronize the Mall. ${ }^{17}$

The effect of the policy has been to drastically curtail teenagers' right of assembly on Mall premises. Thus, the curfew raises many constitutional issues that are not easily answered. ${ }^{18}$ This comment mainly addresses the issue of whether the privately owned Mall of America is so accessible to the public as to be deemed a public space for state action purposes. If so, the next inquiry must be whether state and federal constitutional rights should be granted at the Mall and, if so, to what extent. The issue is an interesting one because both sides have strong constitutional and emotional arguments and because a teen assembly right on mall property is a relatively new concept. ${ }^{19}$ Between Mall management's right to control its property and the teenagers' right to assemble at the Mall lies a delicate balance. This comment

16. Mall visitors and store owners have lodged complaints regarding the "gangs" of teenagers who stand in large groups in certain areas of the Mall on weekend evenings. However, according to Mall Spokeswoman Teresa McFarland, the main reason the curfew was instituted was to combat violence and promote a safe atmosphere. See Telephone Interview with Teresa McFarland, Spokeswoman for the Mall of America (Oct. 31, 1996) [hereinafter McFarland Interview].

17. See id.

18. Other issues of significance which can only be tangentially covered by this comment include: 1) whether the Mall has a right to exclude such a broad class of people; and 2) whether by doing so the Mall is effectively discriminating against the disproportionately large number of minority teens who go to the Mall on weekend evenings. See infra note 279. See generally Apgar, supra note 14.

19. While the Mall of America's juvenile curfew received national news coverage, it was based on two lesser-known pre-existing curfews. See id. One was the curfew at the Asheville Mall in Asheville, North Carolina, enacted in 1993. See id. The Asheville curfew affects teenagers younger than 16 who are at the mall from 6-9 p.m. on Saturday evenings. See id. According to a spokeswoman for the mall, the curfew was imposed due to "an alarming trend of violent, aggressive, disturbing, lewd behavior that was getting worse. And we didn't want to get a reputation as a bad place to come on a Saturday night." Id. (quoting Mary Evans). In February 1994, the Patrick Henry Mall in Newport News, Virginia, became the second mall to impose such a curfew after teenagers were found with guns and clubs. See id. The curfew proved highly effective with incidents reportedly dropping by $80 \%$. The types of incidents were not elaborated upon. See id. See also Lauren Beckham, Teen Rap Shopping for a Hangout-Malls Consider Evening Curfews to Curtail Crime, Boston Herald, Oct. 14, 1996; The Associated Press, Weekend Curfew at Mall of America Protested by Some, SAN Diego Union-Trib., Oct. 6, 1996.

The Newport News curfew was retracted after it achieved its purpose. See McFarland Interview, supra note 16 . The Asheville curfew, while similarly effective, has not been retracted. See id. Ms. McFarland stated that she regards the Mall of America curfew as akin to the Asheville curfew, therefore establishing the Parental Escort Policy as permanent Mall policy. See id. 
analyzes one set of factors at work in that balance, and, while it respects the Mall owners' rights, it leans in favor of a constitutional right for teenagers to assemble at the Mall.

Thus, this comment challenges the constitutionality of the Mall of America's Parental Escort Policy although no cause of action has yet been filed against the Mall regarding the implementation of this curfew. Indeed, the Minnesota chapter of the ACLU has stated that it will not challenge the curfew because Minnesota constitutional law is not favorable to its cause of action. ${ }^{20}$ However, the Minnesota Supreme Court has not yet decided upon the application of First Amendment ${ }^{21}$ principles to privately-owned shopping malls. Based upon an examination of Minnesota statutory and case law, there is a strong argument to be made for the unconstitutionality of this curfew under existing Minnesota law. ${ }^{22}$ This comment argues that while the Mall of America has a recognized interest in promoting safety on its premises, the breadth of its curfew constitutes a taking of the teenagers' freedom of assembly rights. Before the Mall implemented the Parental Escort Policy, a number of other alternatives already existed that would have made the Mall a safer environment without infringing on any one group's rights. ${ }^{23}$ An in-depth analysis of Minnesota individual liberties protections provides strong authority for supporting teenager assembly rights at the Mall.

Beginning in 1968 with Amalgamated Food Employees Union v. Logan Valley Plaza, Inc., ${ }^{24}$ the United States Supreme Court

20. See Meredith, supra note 7, at B9. Kathleen Milner, legal counsel for the Minnesota Civil Liberties Union, stated that "Minnesota does not apply First Amendment principles to shopping malls." Id.

However, other ACLU attorneys take a more activist approach to challenge the curfew. Chris Hansen, a senior staff counsel at the Manhattan ACLU, stated that the curfew "infringes on the rights of young people .... We don't object to the mall setting up rules of behavior, but we do object ... to punishing the good kids for the behavior of kids that aren't behaving." Meredith, supra note 7, at B9. Similarly, John Roberts, executive director of the Massachusetts chapter of the ACLU, has stated that "[m]alls are private property .... But in the instance of the Mall of America, I think it is a punishment of the innocent based on the fact that some kids act up and act out. It just seems like one of these overkill measures that sweeps way too broadly." Beckham, supra note 19.

21. U.S. CONST. amend. I. The text of the amendment states that "Congress shall make no law respecting an establishment of religion, or prohibiting the free exercise thereof; or abridging the freedom of speech, or of the press; or the right of the people peaceably to assemble, and to petition the Government for a redress of grievances." Id.

22. See discussion infra Part IV.

23. See discussion infra Part V.

24. 391 U.S. 308 (1968). 
has resolved four First Amendment challenges against finding any federal constitutional right to free speech in the settings of privately-owned shopping centers or malls. ${ }^{25}$ In addition to the United States Supreme Court, numerous state courts have considered the issue of First Amendment free speech rights with regard to petitioning and leafleting at privately-owned shopping centers. ${ }^{26}$ However, the right of a shopping center to exclude a certain class based solely on age is an issue of first impression. Malls across the country are watching to see if the Mall of America's curfew succeeds, and, if it does, they may institute their own juvenile curfews. ${ }^{27}$ Were the Mall's curfew successfully challenged, the outcome could have an impact on malls throughout the United States.

This comment presents one framework for analyzing the constitutionality of a private shopping mall curfew while simultaneously applying this analysis to the Mall of America's curfew. Depending on factors unique to each situation, the emphasis on the issues will vary. Part II examines the application of First Amendment free speech principles in private shopping centers in order to: 1) establish the backdrop for the proposed challenge; and 2) draw a correlation between free speech rights and assembly rights on private property. A line of United States Supreme Court cases that have addressed the issue of First Amendment free speech rights in private shopping centers will thus be analyzed in order to determine the Court's stance on the application of such protections in private shopping malls. The most recent in this line of cases is PruneYard Shopping Center v. Robins ${ }^{28}$ which held that state constitutions may afford individuals First Amendment type-rights in privately-owned shopping centers so long as the restrictions do not constitute a taking or otherwise violate the Federal Constitu-

25. See Prune Yard Shopping Ctr. v. Robins, 447 U.S. 74 (1980); Hudgens v. NLRB, 424 U.S. 507 (1976); Lloyd Corp. v. Tanner, 407 U.S. 551 (1972); Amalgamated Food Employees Union, 391 U.S. at 308.

26. See discussion infra notes 84-86 (regarding state court decisions).

27. See, e.g., Karl Vick, Area Malls Watching Curfew and Wondering What's in Store for Them, WASH. POST, Sept. 18, 1996, at A13; Lisa Peterson, Malls in Jersey in No Hurry to Chase Teens-Minnesota Curfew Draws Their Interest, NEwARK STAR-LEDGER, Oct.9, 1996; Curfew Begins at Mall of America, WIS. STATE J., Oct. 5, 1996; Chet Fuller, Curfew Targets Teenagers at Minnesota Mall, ATLANTA J. \& CONST., Oct. 21, 1996; Meredith, supra note 7, at A1.

28. 447 U.S. at 81. 
tion. ${ }^{29}$ PruneYard held that First Amendment rights in private shopping centers may be enlarged under state constitutions. ${ }^{30}$ It did not limit those rights to the freedom of speech. ${ }^{31}$ Because PruneYard applied to all First Amendment individual liberties, it must, therefore, include the right of assembly.

Post-PruneYard state court decisions concerning free speech rights at shopping malls turn on the outcome of four questions: 1) Is the nature of the mall such that in essence it is a public space?; 2) What does the respective state constitution provide in the manner of First Amendment type-rights?; 3) How have those state provisions been interpreted?; and 4) How should they be interpreted in the immediate context? ${ }^{32}$ Thus, Part III answers the first question by taking a detailed look at the Mall of America itself. After an examination of the Mall's establishments and its self-promotion, it will be argued that the privately-owned Mall serves as the new Bloomington downtown and is in all respects except for ownership a public space. Analogous decisions in state courts have created free speech rights at shopping centers based on findings that many larger malls have come to resemble, or in fact usurp, the role of the traditional downtown area. ${ }^{33}$ Based upon this determination, courts have declared these private centers or malls to be so essentially public in nature as to require the protection of certain individual liberties on their premises. Therefore, courts have held that private mall owners' rights to prohibit certain speech must fall to the invitees' First Amendment rights, although reasonable restrictions on the place and timing of the speech are permitted. ${ }^{34}$

Part IV examines the Minnesota Constitution and its interpretation by the Minnesota Supreme Court with regard to its protection of individual liberties. While the Minnesota Supreme Court has never decided an individual liberty challenge in the context of a shopping mall, it has consistently read the state constitution broadly to provide for the protection of individual liberties not enumerated

29. See id.

30. See id.

31. "[N]either appellants' federally recognized property rights nor their First Amendment rights have been infringed by the California Supreme Court's decision recognizing a right of appellees to exercise state-protected rights of expression . . ." Id. at 88.

32. See infra text accompanying notes 84-86.

33. See discussion infra notes 148-61.

34. See id. See also discussion infra notes 84,86 . 
therein. ${ }^{35}$ Minnesota's Human Rights $\mathrm{Act}^{36}$ is another source to be examined in its application to this cause of action.

Part V argues that the curfew's breadth removes it from the sphere of a reasonable regulation on private property, and other methods to address the Mall's safety concerns are proposed.

Finally, Part VI presents affirmative defenses that would likely be raised by the Mall of America in support of its Parental Escort Policy. These include the Mall's strong interest in promoting a safe environment and that dismantling the Parental Escort Policy would result in a taking of private property. The safety factor is a very strong argument in favor of the curfew. The Mall is responsible for the safety of all of its patrons, shopkeepers, and personnel. Nevertheless, the Mall can protect these persons by employing other protective devices (as discussed in Part V) rather than an across-the-board juvenile curfew. By implementing the juvenile curfew, the Mall crossed the line between a welfare and safety measure and a denial of access rights to a group it has made every effort into bring to its premises.

\section{First Amendment Rights in Privately Owned Shopping Centers}

In a number of cases concerning the right to distribute literature, petition, or solicit signatures on private property, the United States Supreme Court has firmly held that there is no federal constitutional protection of First Amendment ${ }^{37}$ free speech rights on such property. ${ }^{38}$ However, the route the Court has taken to arrive at the current standing has not been without its detours. A brief history of the five major cases ${ }^{39}$ that have shaped this area of the law provides the background for an analysis of how the Mall of America's curfew fits into this historical continuum.

The line of cases starts with Marsh v. Alabama, ${ }^{40}$ which was the first case to recognize free speech rights on private property. ${ }^{41}$

35. See discussion infra notes 202-60.

36. MinN. Stat. ANN., $\S \$ 363.01-.20$ (West $1991 \&$ West Supp. 1998).

37. U.S. CONST. amend. I.

38. See supra note 25 and accompanying text.

39. See Prune Yard Shopping Ctr, v. Robins, 447 U.S. 74 (1980); Hudgens v. NLRB, 424 U.S. 507 (1976); Lloyd Corp. v. Tanner, 407 U.S. 551 (1972); Amalgamated Food Employees Union v. Logan Valley Plaza, Inc., 391 U.S. 308 (1968); Marsh v. Alabama, 326 U.S. 501 (1946).

40. 326 U.S. at 501.

41. See id. at 512 (Reed, J., dissenting). 
The private property in Marsh was Chickasaw, Alabama, a company town owned by the Gulf Shipbuilding Corporation having "all the characteristics of any other American town."42 The homes, shops, streets, and even sewer systems were company owned. ${ }^{43}$ Grace Marsh was convicted of criminal trespass ${ }^{44}$ after she attempted to distribute religious literature on a downtown Chickasaw sidewalk. ${ }^{45}$ When she appealed her criminal trespass conviction, the Court was asked to decide if her free speech rights took precedence over Gulf's property rights, and the Court held that they did. ${ }^{46}$

The Court's analysis was two-fold. First, the Court conducted a detailed fact-finding of the nature of the town. ${ }^{47}$ Placing substance over form, the Court's aim was to discern whether the town was essentially private or public property, regardless of ownership. ${ }^{48}$ Relying on the fact that the town's business district was accessible to any individual wishing to enter, the Court held Chickasaw to be essentially no different from any non-companyowned town. ${ }^{49}$ The Court then balanced the private property interests of the Gulf Corporation with the First Amendment rights of those who entered Chickasaw. The Court found that the more the town invited, welcomed, and served as any other town, the more it lost its ability to prohibit constitutionally protected behavior. $^{50}$ Justice Black, writing for the majority, stated that

42. Id. at 502 .

43. See id. at 502-03.

44. Ms. Marsh was arrested in violation of title 14, section 426 of the 1940 Alabama Code after she was warned that she could not distribute literature without a permit. See id. at 503-04. Furthermore, she was informed that she would be unable to obtain a permit. See id. at 503. When Ms. Marsh refused to leave the sidewalk, she was arrested under this code provision which "makes it a crime to enter or remain on the premises of another after having been warned not to do so." Id. at 504.

45. See Marsh, 326 U.S. at 503.

46. See id. at 508-09.

47. See id. at 502-03.

48. See id. at 504-09.

49. See id. at 503. The Court stated: "In short the town and its shopping district are accessible to and freely used by the public in general and there is nothing to distinguish them from any other town and shopping center except the fact that the title to the property belongs to a private corporation." Id.

50. See Marsh, 326 U.S. at 506. Similarly, the Mall of America is open to all who wish to enter. See generally PUblic Relations DeP'T, MALl of AMERICA, The Place for FUN IN YOUR LIFE (1996) [hereinafter THE PLACE FOR FUN]. Shopping hours are from 10 a.m. to 9 p.m. Monday through Saturday, and 11 a.m. to 7 p.m. on Sunday. See id. Entertainment and summer hours are extended. See id. The Mall is closed two days of the year: Thanksgiving and Christmas Day. See id. 
"[o]wnership does not always mean absolute dominion. The more an owner, for his advantage, opens up his property for use by the public in general, the more do his rights become circumscribed by the statutory and constitutional rights of those who use it." When balancing a property owner's rights against those of the freedoms of press and religion, the latter occupies a "preferred position." 52 Thus, the First Amendment, as applied through the Fourteenth, was held to apply to Chickasaw and to permit Ms. Marsh to distribute religious literature in downtown Chickasaw.

Twenty-two years later, the Court again considered the issue of free speech rights on private property in Amalgamated Food Employees Union v. Logan Valley Plaza, Inc. ${ }^{53}$ Here, for the first time, the Court was deciding a freedom of speech issue within the context of a shopping center. Logan Valley Mall prohibited as trespass picketing on its premises. ${ }^{54}$ When this prohibition was challenged, the Court held that the Logan Valley Mall was as open and accessible to the general public as the Marsh Chickasaw business district. ${ }^{55}$ Authoring the majority opinion, Justice Marshall wrote that

[w]e see no reason why access to a business district in a company town for the purpose of exercising First Amendment rights should be constitutionally required, while access for the same purpose to property functioning as a business district

51. Marsh, 326 U.S. at 506.

52. Id. at 509. The Court stated: "As we have stated before, the right to exercise the liberties safeguarded by the First Amendment 'lies at the foundation of free government by free men' and we must in all cases 'weigh the circumstances and ... appraise the ... reasons ... in support of the regulation ... of [those] rights." Id. (quoting Schneider v. State, 308 U.S. 147, 161 (1939)).

53. 391 U.S. 308,309 (1968).

54. See id. at 311. Weis Markets and Sears Roebuck and Co. were the two companies occupying Logan Valley Plaza. See id. at 310. A sign was posted by Weis on the outside of its store prohibiting "trespass or soliciting by anyone other than its employees on its porch or parking lot." Id. at 311.

55. See id. at 315 . The court noted that

[i]t is clear that if the shopping center premises were not privately owned but instead constituted the business area of a municipality, which they to a large extent resemble, petitioners could not be barred from exercising their First Amendment rights there on the sole ground that title to the property was in the municipality.

Id. 
should be limited simply because the property surrounding the 'business district' is not under the same ownership. ${ }^{56}$

Building upon Marsh, the Court held that Logan Valley Mall could not exclude those members of the public wishing to exercise their First Amendment rights as long as those rights are exercised in a manner consonant with the property's purpose. ${ }^{57}$ The Court did affirm the private property owner's right to regulate First Amendment rights so long as any restrictions were reasonable in nature. ${ }^{58}$

The Court limited the Logan Valley holding four years later in Lloyd Corp., Ltd. v. Tanner. ${ }^{59}$ Here, for the first time, the Court was strictly dealing with a mall situation as opposed to the company town in Marsh or the shopping center in Logan Valley. The mall at Lloyd Center was a privately owned, multi-level building containing stores and parking facilities and surrounded by public sidewalks and streets. ${ }^{60}$ However, the Court did not find that the Center lost its private character due to its size, ${ }^{61}$ holding that the public invitation to come to the Center must be compatible

56. Id. at 319. Extending this argument to the Mall of America situation is the focus of Part III of this comment. It is the intention of this comment to prove that the Mall of America functions in much the same way as a downtown business district. Thus, as the Majority exalts substance over form in Logan Valley, so should the Mall's essentially public character be of greater importance than its private ownership.

57. See id. at 319-20. The Logan Valley picketers were stationed outside the Weis supermarket and sought to inform customers that the supermarket's employees were nonunion. See id. at 311. They were located in the parcel pickup area and the adjacent parking lot and posed no interference with customers entering or leaving the store. See id.

In Logan Valley, the Court refused to answer the question whether picketing would be allowed if it was not directly related to the property's purpose. See id. at 320, n.9.

58. See Logan Valley, 391 U.S. at 320 . Therein, the Court recognized the emergence of the shopping center in relation to changing demographic trends: "The large-scale movement of this country's population from the cities to the suburbs has been accompanied by the advent of the suburban shopping center, typically a cluster of individual retail units on a single large privately owned tract." Id. at 324 . Perhaps nothing reflects this shift better than the creation and popularity of the Mall of America.

59. 407 U.S. 551 (1972).

60. See id. at 554-56. Indeed, the Court placed emphasis on the nature of the mall and its societal role through the Court's in-depth discussion of the mall's attributes. See id. at 554. It must also be remembered that the year was 1972 , when malls were still relatively new in the United States. The Mall of America was built 20 years later, and the public's attitude towards malls has evolved and changed with the growth of the shopping giant.

61. See id. at 369 . The Court declared:

Nor does property lose its private character merely because the public is generally invited to use it for designated purposes .... The essentially private character of a store and its privately owned abutting property does not change by virtue of being large or clustered with other stores in a modern shopping center.

Id. 
with the purposes of the stores therein. ${ }^{62}$ Because defendant Tanner went to the mall to distribute handbill invitations to a meeting protesting the Vietnam War, his speech was unprotected because it did not have a direct relationship to the center's purposes. Therefore, over a lengthy dissent authored by Justice Marshall, ${ }^{63}$ it appeared that Lloyd left Logan Valley applicable only to situations in which the speech involved purposes consonant with the purposes of the mall itself.

Four years after Lloyd, the Supreme Court completed its evisceration of Logan Valley in Hudgens v. NLRB. ${ }^{64}$ Hudgens held that Logan Valley did not survive Lloyd in any form and was, therefore, overruled by Lloyd. ${ }^{65}$ The issue in Hudgens was whether striking union members had a right to picket in front of one of their employer's retail stores located in a shopping mall. ${ }^{66}$ Relying on Lloyd for the proposition that privately owned shopping malls retain their private natures, the Hudgens Court held that First Amendment free speech principles were not applicable in a privately owned shopping mall. ${ }^{67}$ The Court stated:

[I]f the respondents in the Lloyd case did not have a First Amendment right to enter that shopping center to distribute handbills concerning Vietnam, then the pickets in the present case did not have a First Amendment right to enter this shopping center for the purpose of advertising their strike against the Butler Shoe Co. ${ }^{68}$

62. Unlike the picketers in Logan Valley, the handbillers in Lloyd had alternative areas available where they could relay their message. The Court noted that Lloyd Center was surrounded by public sidewalks that many Center patrons had to cross on their way to the Center. See id. at 556. Therefore, "[i]t would be an unwarranted infringement of property rights to require [the center's owners] to yield to the exercise of First Amendment rights under circumstances where adequate alternative avenues of communication exist." Id. at 567.

Picketing, demonstrating, distributing handbills, soliciting, and petitioning at the Mall of America are permissible with the prior written consent of the Mall's management. See Mall of America, Conduct Code (1996).

63. The Lloyd decision was 5,4. Justice Marshall, author of the Logan Valley majority opinion, wrote the Lloyd dissent in which Justices Brennan, Douglas, and Stewart joined.

64. 424 U.S. 507 (1976).

65. See id. at 518. The court declared that "[w]e make clear now, if it was not clear before, that the rationale of Logan Valley did not survive the Court's decision in the Lloyd case." Id.

66. See id. at 509.

67. See id. at 520-21.

68. Id. 
The Court so held even though there was a connection between the picketing and one of the stores in the mall, a linkage that was absent in Lloyd. ${ }^{69}$

Most recently, the United States Supreme Court further clarified its Lloyd holding in PruneYard Shopping Center v. Robins. ${ }^{70}$ PruneYard was a large shopping mall in California ${ }^{71}$ whose owner sought to prohibit high school students from gathering signatures protesting a United Nations resolution on mall property. ${ }^{72}$ The California Supreme Court upheld the students' right to petition in the mall under the California Constitution. ${ }^{73}$ Relying on a line of California cases ${ }^{74}$ and interpreting Lloyd not to prohibit the California Constitution from providing greater protections than the First Amendment, the California Supreme

69. Justice Marshall noted in his dissent that Lloyd preserved the right to picket when the picketing is related to the purpose of the property and when other alternatives for communicating the desired message are unavailable. See Hudgens, 424 U.S. at 540.

70. 447 U.S. 74 (1980).

71. Again, the United States Supreme Court placed emphasis on the fact-finding of the lower court in determining the nature of the mall. The Court reiterated the finding of the California Supreme Court that approximately 25,000 people congregated daily at the mall as a result of advertising and "the lure of a congenial environment." Id. at 78.

72. See id. at 77. Appellees were a number of high school students who set up a card table in the mall's central courtyard and who attempted to solicit support for their opposition to a resolution against "Zionism." See id.

73. See Robins v. PruneYard Shopping Ctr., 592 P.2d 341, 347 (Cal. 1979).

74. In so doing, the California Supreme Court cleared up any confusion regarding its own stance on free speech rights on public property. In Diamond v. Bland, 477 P.2d 733 (Cal. 1970), the court permitted free speech rights in a privately owned shopping center. After the U.S. Supreme Court decision in Lloyd, the court reversed Diamond I in Diamond II. See Diamond v. Bland, 521 P.2d 460 (Cal. 1974), cert. denied, 419 U.S. 885 (1974). Justice Mosk wrote a lengthy dissent in Diamond $I I$ in which he compared the shopping center in question to a downtown area in which citizens are granted free speech protections. See id. at 468. In Robins v. PruneYard, the court was presented with two questions: 1) whether Lloyd provided federally protected private property rights such that state constitutions were preempted from providing greater free speech rights on private property; and 2) if not, whether the California Constitution affirmatively protects free speech rights at shopping centers. See Robins, 592 P.2d at 342. Answering the first question, the court held that Lloyd was a First Amendment issue and that references to the Fifth and Fourteenth Amendments only applied to the state action question. See id. at 344. The court read nothing in Lloyd to preempt states from construing their own constitutions more broadly than the Federal Constitution. See id. at 346. Answering the second question, the court held that the California Constitution provided greater free speech protections than the First Amendment and that these protections extend to a private space whose purposes and uses cause it to function as a public arena. See id. at 347. The court was influenced by Justice Mosk's Diamond II dissent holding that the shopping center in question, while privately owned, was so public in nature that it constituted a public space worthy of free speech protections. See id. at 347. 
Court granted the students the right to solicit signatures and distribute handbills under the California Constitution. ${ }^{75}$ This ruling was highly significant because it granted certain free speech rights in privately owned shopping malls, a right the federal government was unwilling to provide.

The United States Supreme Court affirmed this holding. The Court stated that while the Federal Constitution does not protect free speech rights in shopping centers and malls, ${ }^{76}$ it does provide a floor of individual liberties protections that state constitutions can build upon but never go below. ${ }^{77}$ Indeed, the Supreme Court held that Lloyd did not limit states from construing their own constitutions more expansively than the Federal Constitution with regard to individual liberties. ${ }^{78}$ Article 1, section 2 of the California Constitution states that "[e]very person may freely speak, write and publish his or her sentiments on all subjects, being responsible for the abuse of this right. A law may not restrain or abridge liberty of speech or press."79 The Supreme Court of California interpreted this provision to allow a right of "speech and petitioning, reasonably exercised, in shopping centers even when the centers are privately owned." 80 Responding to the mall owner's argument that allowing the students to petition on his property amounts to a Fifth Amendment taking of private property without compensation, the United States Supreme Court held that the right to exclude others was not essential to the use of the property. The Court stated: "There is nothing to suggest that preventing appellants from prohibiting this sort of activity will unreasonably impair the value or use of their property as a shopping center." 81

75. See Robins, 592 P.2d at 347.

76. See PruneYard, 447 U.S. at 81.

77. See id. The purpose of this analysis is to lay the groundwork for arguing for the right to freedom of assembly at the Mall of America under the Minnesota Constitution. This comment argues that PruneYard was intended to extend to all First Amendment type rights including the right to assemble. For older Supreme Court precedent holding that state constitutions may provide a source of greater individual liberty rights than their federal counterpart, see Oregon v. Hass, 420 U.S. 714 (1975) and Cooper v. California, 386 U.S. 58 (1967).

78. See PruneYard, 447 U.S. at 81. The Court stated: "Our reasoning in Lloyd, however, does not ex proprio vigore limit the authority of the State to exercise its police power or its sovereign right to adopt in its own Constitution individual liberties more expansive than those conferred by the Federal Constitution." Id.

79. CAL. CONST. art. I, $\S 2$.

80. Robins, 592 P.2d at 347.

81. PruneYard, 447 U.S. at 83. 
Since no specific harm could be proven by permitting the students access to solicit signatures and distribute information, the Court determined that free speech rights under the California Constitution outweigh private property rights under the Fifth Amendment. ${ }^{82}$ Thus, under PruneYard, the current status of the law is that states may use their own constitutions to build upon First Amendment protections on private property, but state constitutions can never provide fewer rights than those already granted under the Federal Constitution. ${ }^{83}$

PruneYard subsequently bred much state litigation regarding whether state constitutions provided broader free speech rights than those granted under the Federal Constitution in the privately owned property context. In the early 1980 s, a number of courts found in favor of free speech rights. ${ }^{84}$ The tide began to change in the mid-eighties, ${ }^{85}$ and in the nineties the courts have been

82. See id. The United States Supreme Court affirmed the mall's right to impose reasonable regulations to insure that the exercise of free speech rights did not interfere with the mall's regular business operations. See id. Similarly, the Mall of America does have a Conduct Code in place for this same purpose.

83. See id.

84. See Commonwealth v. Tate, 432 A.2d 1382 (Pa. 1981) (holding that when balancing free speech and private property rights, a college could not totally prohibit leafleting on campus); Alderwood Assoc. v. Washington Envtl, Council, 635 P.2d 108 (Wash. 1981) (permitting the collection of signatures at a mall as the mall was functioning as the new downtown). See also Batchelder v. Allied Stores Int'l, Inc. 445 N.E.2d 590 (Mass. 1983) (holding that a candidate for political office had a right to petition at a shopping center based on state election laws); State v. Schmid, 423 A.2d 615 (N.J. 1980) (discussed in Part III); State v. Shack, 277 A.2d 369 (N.J. 1971) (discussed in Part III). For a detailed analysis of state court decisions before 1986, see John A. Ragosta, Free Speech Access to Shopping Malls Under State Constitutions: Analysis and Rejection, 37 SYRACUSE L. Rev. 1 (1986).

85. See Fiesta Mall Venture v. Mecham Recall Comm., 767 P.2d 719 (Ariz. Ct. App. 1988) (declaring that the Fiesta Mall did not constitute the downtown area rather than considering whether the mall met the state action requirement that would allow for signature solicitations); Cologne v. Westfarms Assoc. 469 A.2d 1201 (Conn. 1984) (holding that nothing in the Connecticut Constitution supported free speech rights in a privately owned mall to allow for the solicitation of signatures in support of the proposed ERA Amendment); Woodland v. Michigan Citizens Lobby, 378 N.W.2d 337 (Mich. 1985) (declaring that the Michigan Constitution did not prevent private mall owners from restricting First Amendment rights with regards to the solicitation of signatures at shopping malls); Shad Alliance v. Smith Haven Mall, 488 N.E.2d 1211 (N.Y. 1985) (upholding a privately-owned shopping mall's prohibition against leafleting based on a finding of no state action at the mall); Western Pa. Socialist Workers 1982 Campaign v. Connecticut Gen. Life Ins. Co., 515 A.2d 1331, 1337 (Pa. 1986); Commonwealth v. Tate, 432 A.2d 1382 (Pa. 1981) (holding that the mall was not a downtown district and that political speech at a private mall was not protected speech under the Pennsylvania Constitution); Southcenter Joint Venture v. National Democratic Policy Comm., 780 P.2d 1282 (Wash. 1989) (holding a state action requirement implicit in the state constitution and that the solicitation of political contributions at a privately owned mall was 
almost evenly split. ${ }^{86}$ In December 1994, the New Jersey Supreme Court issued a detailed decision on this subject. ${ }^{87}$ Due to the similarity of the facts of the New Jersey case to the issues surrounding the Mall of America, that case provides the most persuasive authority to be used as a point of comparison with Minnesota caselaw. However, before embarking on an application of PruneYard to Minnesota Constitutional law and the Mall of America, it is necessary to analyze the features of the Mall itself. The point of departure for an analysis of freedom of assembly rights at the Mall of America lies in the nature of the Mall. Since state constitutions apply to state action, ${ }^{88}$ it must be argued and established that the Mall functions not as private property but as a public space. Courts that have found free speech rights at malls have done so based first upon the nature of the mall as a "downtown" area, and based secondly, in conjunction with state First

thus prohibited as the state constitution established rights between the people and their government rather than between people and people, and thus reversing Alderwood's holding that Washington's free speech provision protected speech on private property); Jacobs $v$. Major, 407 N.W.2d 832 (Wis. 1987) (holding that the Wisconsin Constitution's free speech protections did not extend to private property in an action brought by an antinuclear dance troupe which wanted to perform at a private shopping mall). See also State v. Felmet, 273 S.E.2d 708 (N.C. 1981) (upholding the prohibition of petitioning in the parking lot of a privately owned shopping mall).

86. For cases granting free speech rights in privately owned shopping malls, see Westside Sane/Freeze v. Ermest W. Hahn, Inc., 274 Cal. Rptr. 51 (1990) (following PruneYard and permitting leafleting at a privately owned mall); Bock v. Westminster Mall Co., 819 P.2d 55 (Colo. 1991) (allowing political leafleting at a mall due to the state's financial interest in the mall which constituted state action and triggered free speech protections under the Colorado Constitution, but stating that under PruneYard it was unnecessary to find state action when a state constitution is more protective of free speech than the Federal Constitution, as the majority believed to be the case with the Colorado Constitution and declaring the mall the new downtown and public forum); New Jersey Coalition Against War in the Middle East $v$. J.M.B. Realty Corp., 650 A.2d 757 (N.J. 1994) (discussed at length in Part III).

Those cases supporting private property owner's rights to prohibit free speech include Citizens for Ethical Gov't, Inc. v. Gwinnet Place Assoc., 392 S.E.2d 8 (Ga. 1990) (holding that the Georgia Constitution did not protect petitioning on private property); Eastwood Mall, Inc. v. Slanco, 626 N.E.2d 59 (Ohio 1994), cert. denied, 513 U.S. 933 (1994) (holding that the Ohio Constitution's free speech guarantees were no broader than the First Amendment) and Charleston Joint Venture v. McPherson, 417 S.E.2d 544 (S.C. 1992) (holding that the South Carolina Constitution's free speech provisions provided no more free speech protections than the Federal Constitution).

87. See New Jersey Coalition, 650 A.2d at 757.

88. For a fuller explication of the state action requirement, see LAURENCE H. TRIBE, AMERICAN CONSTTTUTIONAL LAW § 18-1, at 1688-1720 (2d ed. 1988). 
Amendment-type provisions. ${ }^{89}$ Following is a detailed analysis of the Mall of America as public arena.

\section{Is the Mall of America the New "Downtown"?}

The Mall of America is the largest retail and entertainment complex in the United States. ${ }^{90}$ From its opening in 1992, there have been over 190 million visits to the Mall with weekly visits ranging from 600,000 to 900,000 depending on the season..$^{91}$ The Mall is located only five minutes from the Minneapolis/Saint Paul International Airport, ${ }^{92}$ a convenient location because over thirty percent of the Mall's visits are made by people from outside a 150 mile radius. ${ }^{93}$ Even foreigners make the Mall of America a stop on their itineraries, if not a focal point, as evidenced by the fact that international visitors account for six percent of the Mall's patrons. ${ }^{94}$ Indeed, the Mall has become such a tourist attraction in the six years since its opening that citizens of each of the fifty states and over two dozen nations have visited it. ${ }^{95}$ As amazing as it may seem, the Mall attracts more visits annually than Disney World

89. Beginning with Marsh v. Alabama, 326 U.S. 501 (1946) the United States Supreme Court spent a good deal of time analyzing the nature of the place where the free speech rights were being asserted. See id. at 502-03. A detailed fact-finding of the situation was important to determine the nature of the space itself, be it a company owned town (Marsh), shopping center (Logan Valley), or mall (Lloyd Corp., Hudgens and PruneYard). State courts, therefore, place much emphasis on the nature of the shopping center or mall in question when deciding whether to find for free speech rights at these locations.

90. See At A Glance, supra note 1.

91. See id.

92. See id.

93. See TOURISM, supra note 3. In 1994 alone, more than 22,000 people in the United States participated in a same-day, low-cost airfare package on Northwest Airlines that brought them to the Mall for one shopping day. See id. A continuous bus service leaves every half hour from the airport going to the Mall. See id.

94. See id.

95. See id. As Mall literature proudly states, people from the following countries have been to the Mall: Australia, Austria, Brazil, Canada, China, England, France, Finland, Germany, Guam, Hong Kong, India, Indonesia, Ireland, Israel, Italy, Japan, Kuwait, Mexico, the Philippines, Russia, Saudi Arabia, Singapore, Spain, Sweden, Taiwan and Thailand. See id. Over 30,000 organized tour groups and over 800 Japanese groups have visited the Mall. See id. In order to accommodate many of these guests, the Mall of America Grand Hotel is located on the premises. See THE PLACE FOR FUn, supra note 50. A second hotel, the Doubletree Grand Hotel at Mall of America, is located across the street from the Mall and advertises itself as the "official hotel across from the Mall." MAP AND DIRECTORY, supra note 4 . 
and the Grand Canyon combined. ${ }^{96}$ Clearly, the Mall has established itself in the American iconographic landscape. ${ }^{97}$

The Mall complex itself is awesome both in its grandness and by the attention to detail which went into its design. The Mall encompasses 4.2 million square feet ${ }^{98}$ with a gross leaseable retail space of 2.5 million square feet. ${ }^{99}$ The rest of the space is allotted for entertainment. ${ }^{100}$ The Mall is so vast that a walk around one of its four level covers a distance of .57 miles. ${ }^{101}$ The Mall has four national chain anchor stores: Bloomingdales, Macy's, Nordstrom's, and Sears; and five-hundred twenty smaller stores located amongst the anchors. ${ }^{102}$ The Mall is in the shape of a square, and there are four "streets"103 connecting the anchors stores in which the smaller stores are located. Each of the four "streets" has a distinct and separate character. ${ }^{104}$ The Mall of America's promo-

96. See September Press Release, supra note 9. Justice Black's Marsh v. Alabama, 326 U.S. 501 (1946), majority opinion is thus recalled that "[t]he more an owner, for his advantage, opens up his property for use by the public in general, the more do his rights become circumscribed by the statutory and constitutional rights of those who use it." Id. at 506. While the context in which these words were written pertained to a company-owned town, they are not limited to company-owned towns only. They do in fact have significant bearing on the Mall of America. The owners of the Mall have made their property as accessible to the public as possible, and the Mall should fall within the Marsh penumbra of public places, regardless of private ownership.

97. After a visit to the Mall of America, the columnist Molly Ivins wrote, "[g]reat Caesar's armpit! Sweet suffering catfish! Holy gamoly! I have been to the pyramids of America. I have seen the cathedral of commerce. Our Parthenon, our Coliseum, our Chartres. I have been to the Mall of America, the world's largest shopping mall." PUBLIC RElations DeP'T, Mall of AMERICA, QuOTABles (1996) [hereinafter QuOTABLES].

98. In order to grasp how large the Mall of America actually is, consider the following facts: the Mall can hold 32 Boeing 747s; it is as large as seven Yankee Stadiums; Moscow's Red Square can fit into the Mall five times, as can 20 of St. Peter's Basilicas in Rome. See Public Relations Dep'T, Mall of america, Fun Facts \& Quotables (1996) [hereinafter FUN FACTS \& QUOTABLES].

99. See AT A GLANCE, supra note 1. Gross leasable area is the total floor space available for merchants. See id. Occupancy as of March 1995 was at $93.5 \%$. See id.

100. See John Sprenkle \& Michael Tubridy, Mall Openings Continue at Moderate Pace, INTERNATIONAL COUNCIL OF ShOPPING CENTERS RES. Q., Summer 1996, at 13.

101. See Fun FACTS \& QUOTABLES, supra note 98.

102. See ThE PlaCE For Fun, supra note 50. The Mall literature states, "[t]here are stores to fit every budget from discount to moderate to upscale ...." Id. These include specialty stores and national retail chain stores such as Filene's Basement, B. Dalton Books, Banana Republic, Ann Taylor, and Eddie Bauer Home Collection. See id.

103. See Public Relations Dep'T, Mall of America, User Friendly (1996) [hereinafter USER FRIENDLY].

104. See id. East Broadway, which connects Bloomingdale's and Sears, is modeled with chrome to provide a futuristic look. South Avenue, the "street" between Macy's and Bloomingdale's, is described as a "chic, sophisticated shopping avenue" while the West 
tional information states: "It is . . one of the most user friendly architectural designs in the country."105

In addition to the shopping, the Mall attracts adults to its entertainment and nightlife. The Mall contains nine nightclubs, a fourteen-screen movie theater, an eighteen-hole miniature golf course, a sports bar, a comedy club, and a wide variety of restaurants. $^{106}$ In order to accommodate adults who visit the Mall with small children, the Mall offers four family rooms designed for infant care. ${ }^{107}$ Not only do these rooms provide space to feed and change babies, but they also contain microwaves for heating bottles and vending machines that sell baby needs. ${ }^{108}$

Parents can enroll their teenagers in the Metropolitan Learning Alliance, which is a high school located in the Mall. ${ }^{109}$ Adults can earn a college degree from the National College, the first college campus located in a shopping mall. ${ }^{110}$ Courses include accounting, marketing, human resources, computer, and business. ${ }^{111}$ The College offers its classes during the day, at night, and on Saturdays. $^{112}$ Other conveniences for families and adults include a bank, a post office, a health and dental clinic, seven ATM machines sites, a copy center, a hotel/car rental information phone, four Mall of America Guest Service Centers, and two travel offices. ${ }^{113}$ The Mall of America's promotional materials include one fact sheet entitled "User Friendly" which details all of the conveniences located in the Mall. In addition to the amenities already listed, the Mall contains forty-four escalators and seventeen elevators and is

Market is modeled on a European railway station. See id. Lastly, the North Garden is designed in the manner of a park containing gazebos and trellises. See id.

105. Id.

106. See Public Relations Dep'T, Mall of America, Restaurants \& Nightclubs (1996) [hereinafter Restaurants \& NightClubs]; Public Relations DeP'T, Mall of America, THE Place For Fun IN YOUR LifE (1997). The range of restaurants consists of everything from the trendy Planet Hollywood and a Rainforest Café to the more upscale Napa Valley Grille and California Café. See RESTAURANTS \& Nightclubs, supra.

107. See Public Relations Dep'T, Mall of America; Family Fun (1996) [hereinafter FAMILY FUN].

108. See id.

109. See USER FRIENDLY, supra note 103.

110. See Public Relations Dep't, Mall of america, Celebrating 5 years of Bringing THE WORLD to Minnesota! (1997) [hereinafter Celebrating 5 Years].

111. See id.

112. See id.

113. See id. Not to be forgotten is the Chapel of Love. Over 1000 couples have been married at the Mall of America since 1994. See PUBlic Relations DeP'T, Mall OF AMERICA, FUn FACTS \& QUOTABles (1997); Celebrating 5 YeARS, supra note 110. 
handicapped accessible. The Mall provides over 20,000 free parking spaces, and no vehicle parked on any one of the parking ramps is farther than three hundred feet from one of the Mall's twenty-three entrances. ${ }^{114}$

While there are numerous stores and attractions for adults and families, the Mall has made a concerted effort to attract youth. There are a variety of attractions and stores in the Mall which are intended to bring young people to the Mall complex. In the center of the Mall is Knott's Camp Snoopy, a seven-acre family theme park, which is the largest indoor theme park in the United States. $^{115}$ Knott's Camp Snoopy contains seventeen rides, nine eating places, shopping, and various other forms of entertainment. ${ }^{116}$ That the park is oriented toward older youth as well as young children is evidenced by the rides inside the park: a log chute, a roller coaster, and a "multisensory Mystery Mine Ride." 117 Mall literature distinguishes these rides from those intended for youngsters; such rides include the Li'l Shaver roller coaster, Americana Carousal, and the Balloon Race. ${ }^{118}$ Restaurants in the park such as the Hormel Food Court and Kemp's Cookies and Cream are oriented toward all age groups while the fast food eateries in the east wing are heavily frequented by teenagers. ${ }^{19}$ Other youth attractions at the Mall include StarBase Omega, an interactive laser game in which players are trained and outfitted in special gear, and Tempus Expeditions, a shopping center that provides an adventure-filled learning experience. The Mall also contains such teenage-oriented stores as a super sports store, a Tekno Comix interactive entertainment store, a holograms store, and a "junkyard" selling "grunge" clothing. ${ }^{120}$

114. See Destination Planning Guide, supra note 2.

115. See id. See also FAMILY FUN, supra note 107.

116. See id. Also of interest is the 1.2 million gallon walk-through aquarium and the LEGO Imagination Center. See AT A GlANCE, supra note 1. Described as "an enormous LEGO showplace designed as a three-level fantasy LEGO factory," it is a place in which "[v]isitors are welcome at any time to come in and play with LEGO bricks and Duplo blocks at no cost." FAMILY FUN, supra note 107.

117. See PUblic Relations Dep'T, Mall of America, KNotT's Camp Snoopy (1996) [hereinafter KNOTT'S CAMP SNOOPY].

118. See id.

119. See id.

120. See Public Relations Dep'T, Mall of america, Unique \& innovative RETAILERS (1996) [hereinafter UNIQUE \& INNOVATIVE RETAILERS]. 
The Mall's concerted effort to welcome and invite teenagers to its premises is relevant to the teenagers' use of the Mall. Referring to the mall managements in New Jersey Coalition, the New Jersey Supreme Court stated that "[ $t]$ he issue is whether defendants" actual conduct, the multitude of uses they permitted and encouraged, including expressive uses, amounted to an implied invitation and, if so, the nature and extent of that invitation." ${ }^{21}$ Little if any doubt exists that the Mall of America openly welcomed all teenagers to its premises and that the extent of this invitation, by its very nature, included activities other than those enumerated herein.

These are the highlights of some of the most popular attractions at the Mall of America. What can hopefully be learned from this information is that the Mall of America is a massive, allencompassing structure. As previously stated, ${ }^{122}$ almost all of the preceding information comes from the Mall of America's promotional literature. The Mall advertises itself as any other profitmaking endeavor would: by accentuating the positives. ${ }^{123}$ Hence, the promotional materials include a detailed separate listing of all conveniences offered at the Mall, a listing of all family activities, and a listing of the restaurants and nightclubs on the premises. The Mall aims to please everybody and advertises as such. ${ }^{124}$ Once the Mall has so invited and catered to the public, the question presents itself whether it then is deemed a public space for First Amendment purposes.

An appropriate place to begin this inquiry is the Mall's literature itself. In one of its brochures entitled "The Place for Fun in Your Life," the Mall management states that the Mall was

121. New Jersey Coalition Against War in the Middle East v. J.M.B. Realty Corp., 650 A.2d 757, 772 (N.J. 1994).

122. See supra note 1 and accompanying text.

123. The Mall uses numerous superlatives in its promotional material, i.e. "the nation's largest retail and entertainment center," USER FRIENDLY, supra note 103; "Knott's Camp Snoopy, Mall of America's lively centerpiece, is the largest indoor family theme park in the nation ...." KNOTT's CAMP SNOOPY, supra note 117. "[W] hat sets Mall of America apart from typical shopping malls is its unique range of retail, offering quality, variety and value, from luxury to the basics . ..." UNIQUE \& INNOVATIVE RETAILERS, supra note 120. "Mall of America is host to some of the finest eating establishments-all under one roof ...." RESTAURANTS \& NIGHTCLUBS, supra note 106.

124. Indeed, a poll taken from November 27 to December 3, 1995, revealed that $70 \%$ of Mall shoppers combine a trip to the Mall with a visit to Knott's Camp Snoopy or the Mall's nightclubs and bars. Sally Apgar, Minnesota Poll, MinNEAPOLIS-ST. PAUL STAR-TRIB., Dec. 10,1995 . 
"[d]esigned as a city within a city." 125 By naming the four wings of the Mall "streets", the Mall refers to itself in terms of a downtown area. "While the Mall's extensive skylight system allows the visitors to feel as though they're outdoors, it's guaranteed perfect weather and 70 degrees!" 26 Proof that Mall management wants the Mall to be considered a self-contained city is evidenced by the following quote from the Mall's promotional packet:

Yet the most striking thing about the mall is that [it] seems to be providing what American cities themselves-at least the downtown shopping districts of American cities-once provided: a bright, vibrant, secure-feeling atmosphere where crowds of people congregate day and night, an immaculate and thriving shopping area where thousands of people-more than 600,000 during an average week - can spend time browsing, dining or going to the theater, a clean and well-run place that, while one is inside it, seems to be the center of things. ${ }^{127}$

Not only does Mall management consider the Mall to be an indoor city, but the contents of the Mall are the type found in a city. In the Mall, one may: enroll one's teenager in school; get a college degree; go to the health or dental clinic; make a bank transaction; go to the post office; dine at any number of restaurants; go to the movies or a nightclub; and shop to satisfy basically every need. Evidence that the Mall is a rival "downtown" is exemplified by the fact that the year it opened, business in downtown Minneapolis was "off" approximately twenty percent; by August 1995, it had stabilized at eight to ten percent. ${ }^{128}$

Perhaps the most decisive evidence that the Mall of America functions as the new downtown comes from the people who live

125. THE PlaCE FOR FUN, supra note 50 (emphasis added).

126. Celebrating 5 YeARS, supra note 110.

127. QUOTABLES, supra note 97 (quoting Bob Greene, columnist of The Chicago Tribune).

128. See Sally Apgar, It's a Megamall World After All, MINNEAPOLIS-ST. PAUL STAR TRIB., Aug. 11, 1995, at 1A [hereinafter It's a Megamall World]. Other factors, such as the renovation of other large shopping centers, may have also contributed to the decline. However, as one area retail consultant stated in a 1995 interview: "[P]eople from out of the city who used to go downtown now go to the Mall of America." Id. Indeed, a telephone poll taken by Star-Tribune/WCCO-TV over November 27 to December 3, 1995, found that of 1,018 adults polled, $18 \%$ who shop at the Mall of America shop in downtown St. Paul less than in years past. The poll also found that downtown St. Paul, along with two other shopping centers, was losing the most customers to the Mall of America. See Sally Apgar, Confounding Critics, Mall Displays Staying Power, MINNEAPOLIS-ST. PAUL STAR-TRIB., Dec. 10, 1995, at 1B [hereinafter Confounding Critics]. 
with the Mall on a daily basis. Larry Carlson, a Minneapolis retail consultant, states that " $[\mathrm{t}] \mathrm{h}$ ere are people who will shoot me for saying it, but the mall is serving as a new downtown." 129 One Mall patron has said that "[s]ometimes I go [to the mall] for entertainment. But mostly I go for shopping because everything you need is right in the mall. Downtown St. Paul is more spread out, so you have to go [sic] more places to find what you need. $" 130$

\section{A. Persuasive Precedent-New Jersey Coalition Against War in the Middle East v. J.M.B. Realty Corp.}

Precedent for recognizing the Mall of America as a functioning downtown can be found in numerous cases. ${ }^{131}$ One of the most recent cases-New Jersey Coalition Against War in the Middle East v. J.M.B. Realty Corp. ${ }^{132}$-is also the most persuasive. In 1994, the New Jersey Supreme Court reversed a ruling denying access rights to a group of citizens desiring to conduct a leafleting campaign at ten privately-owned malls. The purpose of the leafleting was to protest United States intervention in the Middle East upon Iraq's invasion of Kuwait in $1990 .{ }^{133}$ In a lengthy decision written by Chief Justice Wilentz, the court held that the nature of the malls was such that they functioned as public spaces and, therefore, they could not deny public free speech access. ${ }^{134}$

The court built its analysis on prior New Jersey caselaw, most specifically upon State v. Schmid. ${ }^{135}$ Schmid held that a private

129. It's a Megamall World, supra note 128. The same article later states "[a]s Carlson and others see it, the Mall of America has become the new town square, the new downtown retail district of the Twin Cities. The combination of entertainment and retail has given people the wide variety of choices that they used to find only in downtown Minneapolis." Id.

130. Confounding Critics, supra note 128 (quoting Ann Scherman). The article states "[l]ike it or not, the megamall has become an integral part of the state's culture and shopping lives of many Minnesotans." Id. The article holds that the latest point of reference in Minnesota is the Mall of America, rather than Lake Woebegon of days of old. See id.

131. See supra notes 84,86 and accompanying text.

132. 650 A.2d 757 (N.J. 1994).

133. See id. at 762 .

134. See id. at 783. The court did hold that the malls could impose reasonable time, place, and manner restrictions on the leafleting. See id. For similar provisions, see Westside Sane/Freeze v. Ernest W. Hahn, Inc., 274 Cal. Rptr. 51, 59 (1990); Bock v. Westminster Mall Co., 819 P.2d 55, 63 (Colo. 1991); Batchelder v. Allied Stores Int'l, Inc. 445 N.E.2d 590, 591 (Mass. 1983); Commonwealth v. Tate, 432 A.2d 1382, 1390 (Pa. 1981); State v. Schmid, 423 A.2d 615,630 (N.J. 1980).

135. 423 A.2d at 615 . 
university could not unreasonably deny the exercise of political speech to anyone who walked onto campus. ${ }^{136}$ Princeton University, although a private institution, invited the public onto its premises to such an extent that the property was deemed public for constitutional purposes, and state free speech principles were held to apply. ${ }^{137}$

Thus, by granting a speech right on private property under the New Jersey Constitution, the New Jersey Supreme Court established a standard to determine when public use necessitates accompanying constitutional obligations. The standard is threepronged: (1) What is the normal use of the property?; (2) What is the extent and nature of the public's invitation to use it?; and (3) What is the purpose of the expressional activity in relation to both

136. See id. at 633. Chris Schmid, who was not a Princeton student, was charged with trespass on private property after he distributed and sold United States Labor Party political materials on campus. See id. at 616.

137. See id. at 631 . In contrast, in 1993 a New Jersey court upheld a criminal trespass ban on leafleting on a campus that was not held to be open to the public. See State v. Guice, 621 A.2d 553 (N.J. Super. Ct. Law Div. 1993). The Superior Court of New Jersey held that Stevens Institute of Technology, a much smaller institution than Princeton University, made a deliberate attempt to maintain the private nature of its campus, and thus its prohibition against leafleting was upheld. See id. at 556.

The New Jersey Supreme Court has a history of expansively protecting individual free speech rights over those of private property owners. In State v. Shack, 277 A.2d 369 (N.J. 1971), the unanimous court held that a private property owner who employs and houses migrant farm workers may not deny the workers the right to receive government visitors wishing to provide them with medical and legal advice. The Court did not support this holding under Marsh because it did not find a direct correlation between a migrant camp and the business district of Chickasaw, Alabama. See id. at 371. Nor did the court base its reasoning upon the New Jersey trespass statute (two government workers were charged with trespass when they entered a camp and refused to leave until they had a private audience with one of the migrant workers), nor upon the Sixth Amendment right to counsel. See id. at 371-72.

Rather, the court held that New Jersey law does not provide the owner of private property with the right to bar access to government services meant for migrant workers. See id. The court chose to ground its holding upon this basis rather than on constitutional considerations because doing so provided the migrant workers with a broader rights base. See id. at 372. As the court stated, "[a] decision in nonconstitutional terms is more satisfactory, because the interests of migrant workers are more expansively served in that way than they would be if they had no more freedom than these constitutional concepts could be found to mandate if indeed they apply at all." Id. Based on the fact that these laborers had little, if any, access to such information, the court held it to be in their best interests to meet with the state workers. See id. at 371-72. Private property rights are not absolute, and the rights and needs of the migrant farm workers outweighed the property owner's right to bar access to his property. See id. at 373 . The court made a point of stating that the property owner is under no obligation to open his property to the general public. See id. at 374. Thus, traveling salesmen or solicitors were not guaranteed entry onto his land unless barring them would deny the migrant workers access to needed items. See id. 
its private and public use? ${ }^{138}$ Considering Schmid, New Jersey Coalition held that "[t]his 'multi-faceted' standard determines whether private property owners may be required to permit, subject to suitable restrictions, the reasonable exercise by individuals of the constitutional freedoms of speech and assembly."139

\section{B. The First and Second Prongs of the Schmid Test}

The Schmid test applies to the Mall of America situation because the New Jersey Supreme Court explicitly states that the test is to be employed to protect rights of speech and assembly. ${ }^{140}$ After articulating the test, the Schmid court stated that " $[\mathrm{t}] \mathrm{his}$ is a multi-faceted test which must be applied to ascertain whether, in a given case, owners of private property may be required to permit, subject to suitable restrictions, the reasonable exercise by individuals of the constitutional freedoms of speech and assembly."141 In Schmid, the primary issue concerned the scope of free speech. ${ }^{142}$ However, the court explicitly stated its intention to also apply this test to assembly issues. The New Jersey Supreme Court, applying this test in New Jersey Coalition fourteen years after Schmid was decided, reiterated the intent that assembly rights were to be included in the rights granted protection under the Schmid test. ${ }^{143}$ The court in New Jersey Coalition stated that it would decide the case based on constitutional and common law grounds; ${ }^{144}$ common law "lays a foundation that would vindicate the exercise of speech and assembly rights in this setting." 145 The court then conducted an analysis of New Jersey common law and, from this analysis, held that free speech rights should be granted at the shopping malls; however, reasonable restrictions of this right would be allowed. ${ }^{146}$

138. See Schmid, 423 A.2d at 630.

139. See New Jersey Coalition, 650 A.2d at 761. Similarly, in PruneYard, the United States Supreme Court, while concerned with a free speech issue, held that its ruling covered First Amendment rights, thus encompassing the freedom of assembly. See PruneYard Shopping Ctr. v. Robins, 447 U.S. 74, 81 (1980).

140. See Schmid, 423 A.2d at 630.

141. Id. (emphasis added).

142. See supra note 134 and accompanying text.

143. See New Jersey Coalition, 650 A.2d at 761.

144. See id. at 777 .

145. See id.

146. See id. at 783. It must be noted that the New Jersey Constitution provides a fundamental right of free speech while the Minnesota Bill of Rights does not enumerate a right to assemble. While this makes it easier for the New Jersey Supreme Court to ground 
This precedent for recognizing assembly rights as one of the rights protected by the Schmid test weighs strongly in favor of recognizing this right in a mall setting. Because this comment advocates using the Schmid test as the standard against which the Mall's Parental Escort Policy must be measured, it is of primary importance that the test encompasses the right of assembly. Further, New Jersey Coalition is the case most akin in scope to the Mall of America cause of action. As it is argued that the New Jersey Coalition precedent (for finding the New Jersey malls to be public arenas) is strongly persuasive with regard to the Mall of America, ${ }^{147}$ the New Jersey Supreme Court's recognition that the Schmid test encompasses assembly rights should also be very persuasive. ${ }^{148}$ Once recognized as such, the Minnesota courts can rely on their common law tradition of extending individual liberties to decide whether that tradition should be extended to encompass assembly rights at malls. The Schmid test encompasses the right to assemble on private property, the issue in question at the Mall of America, and will thus be applied herein.

A comparison of the New Jersey Supreme Court's findings in New Jersey Coalition with the situation at the Mall of America assists in the determination of whether the Mall of America should be deemed a functioning downtown. Under the first and second Schmid prongs (which were jointly considered in New Jersey Coalition), the court conducted a detailed fact-finding into the normal use of the private property on which the restrictions were imposed. In New Jersey Coalition, the defendants were ten very large enclosed shopping centers, ${ }^{149}$ nine of which were regional

its decision, the lack thereof should not hinder the Minnesota Supreme Court. Again, an argument can and should be made under article I, section 16 of the Minnesota Bill of Rights for a right of peaceful assembly. See discussion infra Part IV.

147. See discussion infra notes 148-61.

148. The Supreme Court of Pennsylvania cited Schmid in deciding a case of petition rights on a college campus. See Commonwealth v. Tate, 432 A.2d 1382 (Pa. 1981). In holding that a private Pennsylvania college must allow peaceful leaflet distribution (although certain restrictions were allowed), the court cited the recent Schmid decision holding that freedoms of speech and assembly apply to the distribution of political materials at Princeton University. See id. at 1390. After citing Schmid, the court stated that being "[m]indful of both this Commonwealth's great heritage of freedom and the compelling language of the Pennsylvania Constitution, we likewise hold that, in certain circumstances, the state may reasonably restrict the right to possess and use property in the interests of freedom of speech, assembly, and petition." Id.

149. At various times the opinion refers to them as both shopping centers and as malls. With the exception of Woodbridge Center, the defendants were all, as their names suggest, 
centers. ${ }^{150}$ The regional centers each had from 93 to 244 tenants including department stores, restaurants, banks, entertainment venues, travel agencies, hair salons, doctor's offices, and parking facilities that held from 3,075 to 9,000 vehicles. ${ }^{151}$ With gross leasing areas ranging from 300,000 to $1,000,000$ square feet, each of these regional malls is considerably smaller than the Mall of America, with its gross leasing area of 4.2 million square feet. ${ }^{152}$ Each of the ten malls permitted non-shopping activities on its property; some involved community and political speech. ${ }^{153}$

The court continued its factual analysis by examining statistical information regarding the place of the mall in American life. Citing statistics from shopping center authorities, the court tracked the growth of the shopping center and the simultaneous decline of many downtown shopping districts. ${ }^{154}$ The court was so persuaded by its findings that it held that "[r]egional and community shopping centers significantly compete with and have in fact significantly displaced downtown business districts as the gathering point of citizens, both here in New Jersey and across America."155 Asserting that shopping malls have become an integral part of the American landscape, the court found that malls have evolved to the point where the larger ones serve as the new downtowns. ${ }^{156}$

Considering the public's invitation to use the property (the second Schmid prong), the court found that the contents of the mall and the easy access to them justified the holding that the private property was dedicated to public use. ${ }^{157}$ The New Jersey Coalition court could have been referring to the Mall of America when it held that "there is no property more thoroughly 'dedicated' to public use than these regional and community shopping centers,

malls: The Mall at Short Hills, Cherry Hill Mall, Hamilton Mall, Monmouth Mall, Quakerbridge Mall, Livingston Mall, The Mall at Mill Creek, Riverside Square, and Rockaway Townsquare.

150. The tenth, a community center, was smaller in size and had less variety of stores than the regional centers. Despite this fact, the court included it in its holding. The gross leasable area of a community center ranges from 100,000 to 300,000 square feet. See New Jersey Coalition, 650 A.2d at 763-74.

151. See id.

152. See supra notes $98-99$ and accompanying text.

153. See New Jersey Coalition, 650 A.2d at 764.

154. See id. at 766-68.

155. Id. at 766 (emphasis added).

156. See id.

157. See id. at 771-72. 
a public use so pervasive that its all-embracing invitation to the public necessarily includes the implied invitation for plaintiff's leafleting." 158 The court based this holding equally upon: (1) the nature of the stores in the malls and (2) the public invitation to come the malls. ${ }^{159}$

The Mall of America has established its reputation as a complex that caters to almost every need and interest imaginable. In doing so, it has made a concerted effort to welcome people of all ages to its premises in order that they may partake of all that it has to offer. Like the malls in New Jersey Coalition, the Mall of America opened its doors not only for shopping and entertainment purposes, but for the by-products thereof: the space that provides places to sit down, relax, talk, or simply roam. Indeed, the New Jersey Supreme Court noted that malls are intentionally designed to provide breathing space to make them more attractive. ${ }^{160}$ Such space is intended to provide an additional reason for going to the mall. This is to be distinguished from a strip-shopping center which provides neither shelter from inclement weather nor the multitude of places on which to sit down and relax. The court held that such "non-retail uses, expressive and otherwise, underline the allinclusiveness of defendant's invitation to the people."161 Since the malls act as a community gathering place, the court held that they could not unreasonably prohibit community activities on their premises. $^{162}$

Predating New Jersey Coalition is older precedent recognizing free speech rights at privately-owned shopping centers or malls. ${ }^{163}$ Based on this precedent, and in particular the similarities between the malls at issue in New Jersey Coalition with the Mall of America,

158. See New Jersey Coalition, 650 A.2d at 771-72.

159. See id. at 773-74. "The multiplicity of uses reflects the intention to bring the entire community-its citizens and its activities-into the center. The uses and invitation, in effect, reconstitute the community, conveniently, under one roof." Id.

160. See id. at 773.

161. Id.

162. See id.

163. See Bock v. Westminster Mall Co. 819 P.2d 55, 62 (Colo. 1991) (holding that "we are also persuaded that the Mall functions as the equivalent of a downtown business district"); Alderwood Assoc. v. Washington Envtl. Council, 635 P.2d 108, 117 (Wash. 1981) (holding that " $[\mathrm{t}]$ he shopping center now performs a traditional public function by providing the functional equivalent of a town center or business block"); Robins v. PruneYard Shopping Ctr. 592 P.2d 341, 347 (Cal. 1979); Batchelder v. Allied Stores Int'l, Inc., 445 N.E.2d 590, 591-92 (Mass. 1983). The latter two cases place substantial emphasis on the nature of the mall in question. 
there is a secure basis for asserting that the Mall of America functions as a Bloomington/Minneapolis downtown district. The third prong of the Schmid test-the compatibility of the free speech exercised with the use of the property-is necessary to complete the analysis. This prong is in fact the most important prong for analysis purposes. While the normal use of the property and the nature of the public's invitation to use it ${ }^{164}$ are relatively easily analyzed, the third prong is the decisive prong of the analysis: what is the nature of the teenagers' actions at the Mall, and can those actions be protected under the state constitution? It has been shown in Part II that no federal First Amendment rights exist on private property. However, a right such as freedom to assemble at the Mall of America may be granted by the Minnesota Constitution. Numerous issues must be considered in granting such a right, the most important of which is the nature of the teenagers' actions at the Mall.

\section{The Third Prong of the Schmid Test-The Nature of the Teenagers' Presence at the Mall on Weekend Evenings}

"The main issue is they [teens] yell and use abusive language and for the most part don't respect authority," said Teresa McFarland. "The majority of the kids don't act that way but the small percentage who do ruin it for the rest."165

The purpose of the expressional activity in relation to both the Mall's private and public use goes to the heart of the curfew. ${ }^{166}$ Beginning with the basic facts, anywhere from 2,000 to 3,000 teenagers go to the Mall of America on weekend evenings, and the majority of the teens are black. ${ }^{167}$ Weekend nights are the only time when large groups of black teenagers visit the Mall. ${ }^{168}$

164. See supra Part III.

165. Apgar, supra note 14.

166. The last prong of the Schmid test was discussed separately and in great length by the court. As this prong concerns constitutional considerations of First Amendment type rights, it is perhaps the most weighty of the three prongs.

167. See Meredith, supra note 7; Karl Vick, Mall and Order in Minnesota, WASH. PosT, Sept. 18, 1996, at 1A (stating that "the Mall of America prides itself on its good relations with the community, and although management flatly refuses to say so, most of the young people gathering on weekend nights are black").

168. See Meredith, supra note 7 (quoting Marcus Wilson, an eighteen year-old who frequents the Mall of America). Yusef Mgeni, President of the Urban Coalition in the Twin Cities, has said that most teenagers who go to the Mall on weekend nights are low income, young people of color. Telephone Interview with Yusef Mgeni, President of the Urban Coalition in the Twin Cities (Sept. 25, 1996). 
While most of the teens go to the Mall to "hang out," some do exercise their shopping power. ${ }^{169}$ The Mall of America has repeatedly stated that it considered and then implemented the curfew because the large groups of teenagers disturbed other shoppers and tenants and posed a possible safety hazard. ${ }^{170}$ Indeed, the behavior exhibited by some of the teens can only be described as obnoxious. Numerous incidents have occurred of teens chasing each other throughout the Mall, loudly using foul language, and even spitting over the railings at shoppers below. ${ }^{171}$ Groups congregate at Knott's Camp Snoopy, the rotunda, and the East Broadway entrance. ${ }^{172}$ Other groups block store entrances, and this intimidates many Mall shoppers. ${ }^{173}$ They often dress in

169. See Meredith, supra note 7. Teenagers choose to congregate along the railings where they can talk and watch other teens. See id. Some shop and are the main customers of certain Mall stores. See id.

170. In June 1996, Teresa McFarland stated that "[w]e are dealing with too many unsupervised kids here who are acting disorderly, causing commotions, intimidating guests and preventing mall merchants from doing business." Apgar, supra note 14. Teresa McFarland has further stated that 80 percent of Mall stores support the juvenile curfew. See Beckham, supra note 19.

Ms. McFarland has also stated:

Well, we've seen a very sharp increase in the number of kids that have been coming to the mall on the weekend nights, and within that a growing percentage of kids are acting up, they're at times getting into fights, we've found weapons on kids, we've had both kids and other guests that have been injured. Now nothing has been serious, but this policy is a pro-active attempt of poten-to-to prevent the potential for something more serious to happen.

Interview with Teresa McFarland, Spokeswoman for the Mall of America (Oct. 6, 1996) (NBC television broadcast).

However, as the store manager of the Nature Company stated, "[t]here are tons of good kids out there who are being punished by this ... [a]nd I think it's going to affect our traffic." Haga, supra note 7, at 4 (quoting Linda Korenby).

171. See Meredith, supra note 7.

172. See Kimberly Hayes Taylor, Mighty Moms Make Mark at Megamall, MinnEAPOLISSt. Paul Star-Trib., Apr. 27, 1996.

173. See id.

On Saturday nights, large groups of young people have begun to congregate. No one likes to use the word "gangs," and in our racially sensitive times mall officials are reluctant to discuss the racial tensions inherent in what has gone on. But it has been reported that problems arise when, according to the Minneapolis StarTribune, the young people begin "blocking store entrances, intimidating other shoppers and sometimes walking in groups that swell to 50 people."

Greene, supra note 10. The Conduct Code handed out to teenagers entering the Mall includes the provision that "[a]ppropriate non-offensive attire, including shirts and shoes, must be worn." Mall of America, Conduct Code (1996). 
what is assumed to be gang-related apparel, which further frightens some Mall shoppers. ${ }^{174}$

Prior to the curfew, the Mall had a Conduct Code in place ${ }^{175}$ and Mall guards were required to ask teenagers in groups of three to keep moving. ${ }^{176}$ However, while the Mall has its own security staff, management decided something more needed to be done to deal with the number of unsupervised teens. Thus, they originally implemented three new methods: (1) added security; (2) a Youth Liaison Program; and (3) the Mighty Moms. ${ }^{177}$ The Mighty Moms program has been very successful. It consists of nineteen mothers, eighteen of whom are black, who are present at the Mall on weekend evenings and serve to diffuse confrontations between Mall security and the teens. ${ }^{178}$ Often a yelling match erupts

174. Paul T. Barnes, a shopkeeper at the Mall, has stated that on weekend nights many of his older customers are scared away by the teenagers who congregate outside his store, "70 percent of them under the age of 20 and minority and wearing gang-related apparel .... [A] lot of people are not used to seeing large numbers of kids and large numbers of minority kids." Meredith, supra note 7 .

Mall management has presented no evidence that fewer people have visited the Mall since the gun-related incidences. An issue that presents itself is whether Mall management intended the curfew not only to keep out the few violent teens, but also to provide an atmosphere more conducive to shoppers who feel intimidated by the large number of minority teens at the Mall. The Mall could have banned the violent and disruptive teenagers to achieve the first goal. With only a handful of gun related incidences, it surely is practical to provide Mall security, and especially security posted at Mall entrances, with pictures and names of the violent teens, in order that they can be recognized and refused entrance to the Mall. The Mall firmly denies a motive for implementing the Parental Escort Policy other than keeping the Mall environment safe. See Meredith, supra note 7 (quoting both Teresa McFarland and Virgil Heatwole). Such an analysis into the Mall's motives is beyond the scope of this comment, but the issue is raised for further inquiry.

175. The Conduct Code of the Mall of America is a small, $51 / 2 \times 81 / 2$ " piece of paper with seven bullet headings that serve as the rules. The headings cover everything from disorderly conduct, loitering, and picketing, to attire and the disallowance of pets. At the bottom of the paper, in smaller print, is the information regarding the Parental Escort Policy. It includes the information necessary for obtaining a Minnesota State Identification Card which allows teenagers without driver's licenses or passports to provide acceptable identification.

176. See Taylor, supra note 172.

177. See September Press Release, supra note 9.

178. As one newspaper article states, the Mighty Moms have a good rapport with the teens because "the 'moms' say they can speak the same language. They may use the same words as security officials, but with a different tone, a gentler touch." Taylor, supra note 172. The Mighty Moms are paid $\$ 20$ per hour for five hour shifts and are trained, as they say, in "verbal judo." See Karlen, supra note 9 . While security and police handle violent incidences at the Mall, the Moms "are especially effective in heading off incidents that can be defused better with a friendly chat than with a badge." Id. The fact is, most kids will listen to a mom. Not only is there less authority tension between the Mighty Moms and the teenagers, but there is less (if any) racial tension as well. 
between a teen (or group of teens) and Mall security when the teens are forced to leave the Mall due to a conduct violation. At this point, or before tempers rise, the Mighty Moms will step in, talk with the teens, and help them accept the guards' decision while lending the unhappy teens a sympathetic ear. ${ }^{179}$

While the Mighty Moms have been very successful, Mall management believed further action was necessary to cope with what they perceived to be a potential safety risk. Hence, they instituted the Parental Escort Policy. In a September 4, 1996 press release, the Mall's stated rationale behind the policy was to "reduce the growing number of unsupervised youth at the Mall on weekend nights." 180 Mall management obviously believed that parental supervision of anyone younger than sixteen would lead to a safer Mall atmosphere. ${ }^{181}$ As previously discussed, serious violent incidents have already occurred at the Mall; two involved guns. ${ }^{182}$ While no by-standers were hurt, the Mall management implemented the policy because, in its own words, "the risk of a serious incident continues to increase." 183 Indeed, before the policy was put into effect, the Mall Conduct Code was violated numerous times every weekend. ${ }^{184}$ The weekend after the escort policy was implemented, the Mall's press release stated that fewer rules were violated, there were no fights between kids, and more families came to the Mall. ${ }^{185}$

Are the purposes of teen assembly compatible with the uses of the property? The answer to this question depends on which teens are referred to. For the teens who misbehave and are violent, the answer is a resounding no. The Mall of America was never intended to be a baby-sitter for rowdy Minnesota teens who have no other place to go. While the Mall serves numerous

179. When teens are asked to leave the Mall, they are escorted to the transportation center where they are put on a bus that will take them home. See Taylor, supra note 172.

180. September Press Release, supra note 9.

181. Due to the fact that many unsupervised kids go to the Mall of America, the Mall management states that it is "committed to controlling this situation by asking parents or guardians to be accountable for the actions of children in their care." Id. Virgil $\mathbf{H}$. Heatwole, a Mall manager, has said that he "hoped the policy would result in children bringing their parents to the mall. 'I think society itself, we need to look at where parents are today." Meredith, supra note 7.

182. See supra note 10 ard accompanying text.

183. September Press Release, supra note 9.

184. See Public Relations Dep't, Mall of America, Press Release (Oct. 8, 1996) [hereinafter October Press Release].

185. See id. 
purposes, many teens who go to the Mall and gather in large groups on weekend evenings do not partake in either the activities offered or the shopping. Rather, by their presence, they intimidate some people who go there to shop, be entertained, or both. Also, storekeepers have complained that teens do a good deal of shoplifting on weekend nights, further eroding Mall consumerism. ${ }^{186}$ The Mall's owners do have an interest in protecting their investment, and the presence of the rowdy and violent teens does pose a threat to the reputational value of the Mall.

These arguments persuasively establish that violent teenagers and teenagers who continually misbehave should be denied Mall access. However, the arguments do not overcome the fact that the vast majority of teens present at the Mall on weekend evenings do act in accordance with the purposes of the Mall and pose no safety threat. While the Mall would arguably prefer its patrons to participate in the activities it offers, like a downtown district it has opened its space to people who may only want to hang-out. Indeed, as New Jersey Coalition states, the public's invitation to the mall property "is not just an invitation to shop, but to do whatever one would do downtown, including doing very little of anything." 187

Once it has so opened its doors, the Mall of America should not be allowed to close them without greater justification. The fact that some shoppers are intimidated by large groups of teens at the Mall on weekend evenings does not justify the implementation of an across-the-board juvenile curfew. Indeed, as the United States Supreme Court has held, "mere public intolerance or animosity cannot be the basis for abridgment of these [free assembly and association] constitutional freedoms." ${ }^{188}$ The Court so held in 1971 when it struck down a Cincinnati ordinance making it illegal for three or more people to assemble on a sidewalk and conduct themselves "in a manner annoying to persons passing by." 189 As in the Mall of America situation, a charge was also made that the

186. See Sally Apgar, Megamall's Plan for Required Escorts Praised, Assailed, MINNEAPOLIS-ST. PAUl STAR-TRIB., June 21, 1996, at 1B.

187. New Jersey Coalition Against War in the Middle East v. J.M.B. Realty Corp., 650 A.2d 757, 761 (N.J. 1994) (emphasis added). The court further stated that the malls have "substantially displaced the downtown business districts as the centers of commercial and social activity." Id. at 767 (emphasis added).

188. Coates v. City of Cincinnati, 402 U.S. 611, 615 (1971).

189. Id. at 611 . 
ordinance was enforced disproportionately: ${ }^{190}$ "[A]nd such a prohibition, in addition, contains an obvious invitation to discriminatory enforcement against those whose association together is 'annoying' because their ideas, their lifestyle, or their physical appearance is resented by the majority of their fellow citizens."191 Due to the fact that the majority of the teens who are at the Mall on weekend evenings are black and the patrons are white, the appearance of a discriminatory motive in implementing the curfew is present. The teens speak and dress differently from the older adults at the Mall, and it is their appearance and speech which older people find intimidating. If some Mall patrons feel intimidated by seeing the large groups of black teens at the Mall, such feelings do not justify a prohibition on the teenager's access to the Mall. ${ }^{192}$

Furthermore, the Mall has not stated or implied that fewer people go to the Mall due to teen misbehavior, and no statistics have shown that the Mall's revenues have decreased following the teen shooting incidents. As Mall spokeswoman Teresa McFarland has said, most of the teens at the Mall are well behaved. She stated: "We have a lot of unsupervised young people on Saturday nights ... . [T] hey should be supervised by parents or other adults, but they aren't. Most are good kids. But a small percentage won't follow any mall rules or obey any authority figures ..."193 Bob Lutz, the Bloomington police chief, has stated that "[m]ost of the trouble with teens is rowdy behavior and bad language, but nothing criminal." 194 He also says claims of gang activity are overblown: "Gang activity isn't running when you're supposed to walk or swearing." 195 The Mall has even been called safer than the streets. ${ }^{196}$ By May 7, 1996, the Mall had let it be known that a juvenile curfew was under consideration. Lottie Dixon, one of the

190. See id. at 616, n.6. For one allegation that Mall of America employees hand out the Mall rules to black youth more often than to white youth, see Meredith, supra note 7 .

191. Coates, 402 U.S. at 616.

192. See TRIBE, supra note $88, \S 15-18$, at 1409 (stating that "[i]f simply finding another's appearance or habits offensive to hear, see, or think about were enough to justify exclusionary regulation, rights of personhood and indeed of expression would be at an end").

193. Greene, supra note 10 (emphasis added).

194. Apgar, supra note 186.

195. Id. Further, on September 18, 1996, after the gun-related incidents had occurred, Chief Lutz stated: "[L]et's be clear . . . we're talking about non-criminal conduct by a bunch of snotty-nosed kids." See Vick, supra note 167.

196. See Taylor, supra note 172. 
Mighty Moms, was quoted in the Minneapolis-St. Paul Star-Tribune as follows: "[T]he mall, she said, is much safer than the streets." 197

In concluding the Schmid third prong analysis, this comment does not argue that all teens should be allowed in the Mall of America. Those who have displayed violent behavior, whether teens or adults, should not be allowed in the Mall. Those who have repeatedly broken the Mall's Conduct Code do not deserve to be in the Mall. But this comment does not advocate denying access rights to all teens when only a small number misbehave. To stereotype all teens as undeserving to be in the Mall is not simply grossly unfair but, this comment argues, violative of their assembly rights. Little justification can be found in informing the wellbehaved teens that they are not welcome at the Mall unless accompanied by an adult. As the Mall management itself has said, the majority of the teens at the Mall on weekend evenings are wellbehaved. Some of them do shop while they are there, and the curfew has actually hurt some storekeepers who cater to a younger clientele. ${ }^{198}$ Indeed, many storekeepers and customers say that the policy doesn't work because teens who enter the Mall before 6 p.m. and who are not rowdy do not get checked for identification by Mall security. ${ }^{199}$

The Mall specifically encourages teens to come to its premises by catering to their entertainment and shopping needs. ${ }^{200}$ The fact that most of the teens choose to just 'hang-out' on the premises is in no way incompatible with the Mall's purposes. New Jersey Coalition reiterated that the more a private property owner opens his/her property to the public, the "more do his rights become circumscribed by the statutory and constitutional rights of those who use it." 201 The question then arises whether an argument can be made under existing Minnesota constitutional and statutory law for recognizing teenagers' assembly rights at the Mall.

197. Id.

198. For example, Claire's, an accessory store that caters to young girls, now has less weekend business as its shoppers go to other area malls where they do not need escorts. See Preeti Gupta, Mall Workers Give Mixed Reviews to Curfew, MinNEAPOLIS-ST. PAUL STAR TRIB., July 7, 1997, at 6B. See also Apgar, supra note 186.

199. See Gupta, supra note 198.

200. See supra text accompanying notes 115-19.

201. New Jersey Coalition Against War in the Middle East v. J.M.B. Realty Corp., 650 A.2d 757, 775-76 (N.J. 1994) (quoting Marsh v. Alabama, 326 U.S. 501, 506 (1946)). 


\section{Does Minnesota Law Protect Freedom of Assembly Rights on Private Property?}

\section{A. The Minnesota Constitution and Caselaw}

There is no affirmative grant of freedom of assembly rights on private property in the Minnesota Constitution. Furthermore, unlike the Federal Constitution, the Minnesota Constitution has no express provision granting freedom of assembly rights whatsoever. ${ }^{202}$ There is very little Minnesota caselaw on the subject of assembly rights. However, none of these cases approximate the cause of action contemplated by this comment. In 1939, the Minnesota Supreme Court in State v. Winkels ${ }^{203}$ struck down an overbroad assembly statute, while in State v. Hipp $p^{204}$ the state upheld the current unlawful assembly statute. The statute in Hipp has little bearing on the teenagers' cause of action as the statute is meant to provide police action after the fact and the Parental Escort Policy is a preventative measure. The language of the statute states that

[w] hen three or more persons assemble, each participant is guilty of unlawful assembly, which is a misdemeanor, if the assembly is: (1) With intent to commit any unlawful act by force; or (2) With intent to carry out any purpose in such manner as will disturb or threaten the public peace; or (3) Without unlawful purpose, but the participants so conduct themselves in a disorderly manner as to disturb or threaten the public peace. ${ }^{205}$

The Hipp court upheld the constitutionality of the statute by refusing to find it vague or overbroad. ${ }^{206}$ The third case, State $v$. Johnson, ${ }^{207}$ is only tangentially related to assembly rights. John-

202. See U.S. CONST., amend. I.

203. 283 N.W. 763 (Minn. 1939). The statute which was struck down provided that

[w] henever three or more persons, having assembled for any purpose, shall disturb the public peace by using force or violence to any other person or to property, or shall threaten or attempt to commit such disturbance, or to do an unlawful act by the use of force or violence, accompanied with the power of immediate execution of such threat or attempt, they shall be guilty of a riot.

Id. at 764 .

204. 213 N.W.2d 610 (Minn. 1973).

205. MinN. STAT. ANN. $\S 609.705$ (West 1987).

206. See Hipp, 213 N.W.2d at 614-15.

207. 163 N.W.2d 750 (Minn. 1968). 
son was concerned with whether the defendants' had breached the peace in violation of a state ordinance by gathering in downtown Minneapolis to protest the Vietnam War. ${ }^{208}$ The court held that the police officer's attempt to maintain order by arresting them was within the bounds of the ordinance and did not abridge the defendants' rights of free speech and assembly. ${ }^{209}$ The case was decided in favor of the defendants, however, when the court found that there was insufficient evidence to prove that those arrested had actually violated the ordinance. ${ }^{210}$

Thus, there is very little upon which to base an affirmative right for teenager assembly rights in the existing Minnesota assembly caselaw. ${ }^{211}$ However, a court may grant a specific individual liberty by considering the circumstances leading up to a cause of action and using its own precedent as a guide to the type of individual rights previously recognized. Minnesota caselaw provides a rich history of protecting individual liberties that were unimaginable to the writers of the Minnesota Bill of Rights. By working within this rich tradition and recognizing the need for affirmative assembly rights, there exists a strong argument for the creation of an affirmative assembly right under the Minnesota Constitution. $^{212}$

Article I, section 16, of the Minnesota Constitution holds that "[t]he enumeration of rights in this constitution shall not deny or impair others retained by and inherent in the people." 213 Actions

208. See id. at 751.

209. See id. at 754-55.

210. See id. at 755 .

211. While a detailed analysis of federal decisions dealing with assembly rights is necessary for a more complete argument, such analysis is beyond the scope of this comment. Indeed, while the First Amendment of the United States Constitution provides that Congress shall not abridge the peoples' freedom to assemble, similar to the Minnesota Supreme Court, the United States Supreme Court has heard relatively few cases regarding freedom of assembly.

One United States Supreme Court case bearing on the Mall of America situation is Coates v. City of Cincinnati, 402 U.S. 611 (1971). In Coates, the Court struck down a Cincinnati ordinance making it a criminal offense for "three or more persons to assemble ... on any of the sidewalks .... and there conduct themselves in a manner annoying to persons passing by, or occupants of adjacent buildings." Id. at $611 \mathrm{n} .1$. The Court held the ordinance void for vagueness, as "[c]onduct that annoys some people does not annoy others." Id. at 614. For a further discussion of Coates, see supra text accompanying notes 187-90.

212. Although this comment forcefully argues for a right of teenager assembly based on article I, section 16 of the Minnesota Constitution, the Minnesota courts may look to other jurisdictions to help them in their determination of whether such a right ought to be granted.

213. MINN. CONST. art. I, $\$ 16$. 
for the recognition of individual liberties have been successfully brought, in whole or in part, under this clause. ${ }^{214}$ The Minnesota Supreme Court has liberally interpreted this clause, thus providing constitutional protection for individual liberties not specifically enumerated in the state constitution. ${ }^{215}$ Based on the state supreme court's liberal reading of the Minnesota constitution as granting protection for unenumerated individual liberties, it would be in keeping with this reading for the court to recognize teenagers' assembly rights at the Mall of America.

It has been established that under federal law there exist no First Amendment protections at privately owned malls; however, PruneYard affirmed states' rights to interpret their constitutions as providing more individual liberty protections than the Federal Constitution. ${ }^{216}$ The Minnesota Supreme Court has actively utilized its state constitution as a fertile source of individual rights protections. $^{217}$ In 1985, the Minnesota Supreme Court expressly recognized this utilized power in State $v$. Fuller, ${ }^{218}$ a decision which has been heavily relied upon. The Fuller court stated that "[i]t is axiomatic that a state supreme court may interpret its own state constitution to offer greater protection of individual rights than does the federal constitution." 219 Following is an analysis of the Minnesota Supreme Court's interpretation of its state Bill of Rights. This analysis will show that the Minnesota Supreme Court has consistently placed a high premium on individual liberties by supporting their protection through an expansive reading of the state Bill of Rights. By its nature, this survey cannot be conclusive

214. See discussion infra notes $230-54$.

215. See discussion infra notes 230-54.

216. See Prune Yard Shopping Ctr. v. Robins, 447 U.S. 74 (1980).

217. See In re Welfare of E.D.J., 502 N.W.2d 779 (Minn. 1993); State v. Hershberger, 462 N.W.2d 393 (Minn. 1990); State v. Gray, 413 N.W.2d 107 (Minn. 1987); State v. Fuller, 374 N.W.2d 722 (Minn. 1985).

218. 374 N.W.2d at 722 .

219. Id. at 726. The court went on to state that:

Indeed, as the highest court of this state, we are independently responsible for safeguarding the rights of [our] citizens .... State courts are, and should be, the first line of defense for individual liberties within the federalist system. This, of course, does not mean that we will or should cavalierly construe our constitution more expansively than the United States Supreme Court has construed the federal constitution. Indeed, a decision of the United States Supreme Court interpreting a comparable provision of the federal constitution that, as here, is textually identical to a provision of our constitution, is of inherently persuasive, although not necessarily compelling, force.

Id. at 726-27 (citations omitted). 
as to how the Minnesota Supreme Court would rule if the Mall of America's curfew was to be challenged. Rather, it first provides the background for one avenue of analysis the court may utilize in this hypothetical cause of action; secondly, it resolves the issue in a manner consistent with precedent in honoring heretofore unrecognized individual liberties protections. ${ }^{220}$

Unlike the Federal Constitution, the Minnesota Bill of Rights is placed first in the Minnesota Constitution. At least one commentator has noted that this is perhaps as strong an indication as any of Minnesota's commitment to the protection of individual liberties. $^{221}$ The Minnesota Bill of Rights contains seventeen separate sections enumerating the rights granted therein. ${ }^{222}$ However, while it enumerates separate rights, the Bill of Rights is not meant to be exclusive. As previously stated, article I, section 16 of the Minnesota constitution reads: "The enumeration of rights in this constitution shall not be construed to deny or impair others retained by and inherent in the people." 223 Regarding the interpretation of this provision, the Minnesota Supreme Court held in Thiede v. Town of Scandia Valley ${ }^{224}$ that while the state constitution "specifically recognizes the right to 'life, liberty or property'... [it] does not attempt to enumerate all 'the rights or privileges secured to any citizen thereof.",225 Thus, as far back as 1944, the Minnesota high court held it unlawful for the state to

220. Because this cause of action is of first impression anywhere, this background into Minnesota caselaw can do no more than provide the history of the Minnesota Supreme Court's stance regarding individual liberties issues and argue for continued expansive protection in the case of teenagers' assembly rights at the Mall of America. While it will be proven that the Minnesota Supreme Court has consistently broadly interpreted article I, section 16 of its Bill of Rights, this author is well aware that such liberal interpretations may not necessarily translate to an extension of these holdings to the issue at the Mall of America. See Fiesta Mall Venture v. Mecham Recall Comm., 767 P.2d 719, 721 (Ariz. Ct. App. 1988); Southcenter Joint Venture v. National Democratic Policy Comm., 780 P.2d 1282, 1286 (Wash. 1989).

221. See Fred L. Morrison, An Introduction to the Minnesota Constitution, 20 WM. Mitchell L. REV. 287, 299 (1994) (providing a detailed history of the Minnesota Constitution and a framework for raising state claims under the Minnesota Bill of Rights).

222. See MINN. CONST. art. I, \$\$ 1-17. Of special interest to this comment are article I, section 2 (Rights and Privileges); article I, section 13 (Private Property for Public Use); and article I, section 16 (Freedom of Conscience).

223. MinN. CONST. art. I, $\S 16$.

224. 14 N.W.2d 400 (Minn. 1944).

225. See id. at 405 . 
forcibly remove an alleged pauper and relocate him against his will. ${ }^{226}$ The court held that a property owner cannot be forcibly removed from his land and placed in a legal settlement for poor relief reasons even though, in the past, a state statute allowed such state action. ${ }^{227}$ Rather, the individual's right to be free from this restraint on his liberty took precedence over the asserted state interest.

Since Thiede, the Minnesota Supreme Court has continued to interpret its constitution broadly to afford rights not expressly enumerated therein. Indeed, Thiede's support of unenumerated rights, coupled with Fuller's recognition that the Minnesota Constitution may offer more rights than the Federal Constitution, has proved to be a powerful one-two punch for the support of individual liberties under Minnesota constitutional law. For example, citing both Fuller and Thiede, the Minnesota Supreme Court has held that while no express right of privacy is enumerated under its constitution, one exists and is recognized by the Minnesota Constitution. ${ }^{228}$ In State v. Gray, the court was faced with a constitutional challenge to a state sodomy statute. The defendant argued that the statute infringed on his right of privacy to have consensual, for-hire homosexual sex. Holding otherwise, the court decided that while the state constitution does recognize an unenumerated right of privacy, the court would not extend that right to commercial sex. ${ }^{229}$ The court did not decide whether the sodomy statute was unconstitutional when prostitution was not involved. Thus, while the defendant in Gray lost, all Minnesotans

226. See id. at 406 . The court held that town supervisors who continue to unlawfully remove a pauper from his home will be personally liable for actual and punitive damages stemming from the removal. See id. at 407-08.

227. Noting that a man's home is his castle, the court held this concept to be older than the Magna Carta and embedded in both the Declaration of Independence and in the Bill of Rights of the Federal and Minnesota Constitutions. See id. at 405.

228. See State v. Gray, 413 N.W.2d 107 (Minn. 1987).

229. See id. at 114. The Minnesota Supreme Court recognized the federal right of privacy enunciated in Griswold v. Connecticut, 381 U.S. 479 (1965) and extended this right to the Minnesota Constitution. See Gray, 413 N.W.2d at 111. One year before the Gray decision, the United States Supreme Court had decided Bowers v. Hardwick, 478 U.S. 186 (1986), holding that federal guarantees of privacy rights do not encompass the right to engage in homosexual sex. By the time Mr. Gray's case reached the Minnesota Supreme Court, he was preempted from arguing under the Federal Constitution. Although he may have chosen to argue under federal law if able to do so (were Bowers not yet decided), his argument under the Minnesota Constitution had the lasting effect of providing Minnesotans with a recognized right of privacy under their own state Bill of Rights. This right is clear and distinct from a correlative right under the Federal Constitution. 
won as the right to privacy was recognized under Minnesota law. ${ }^{230}$ The court specifically held that Minnesotans' right to privacy under their state constitution equaled that under the Federal Constitution; nevertheless, no specific sections of the Minnesota Constitution were cited to support this conclusion. ${ }^{231}$

The Minnesota Supreme Court has also expanded its constitution's individual liberties protections in the area of criminal law, providing more safeguards to the accused with regard to searches and seizures than does the Fourth Amendment. In In re Welfare of E.D.J. ${ }^{232}$ the court declined to adopt the United States Supreme Court's Fourth Amendment seizure definition in California v. Hodari $D .^{233}$ Hodari held that a seizure only occurs when physical force is used to restrain a person's movements or when a person physically submits to a show of police authority. ${ }^{234}$ This definition was significantly narrower than the Minnesota concept of seizure. Minnesota had been applying the Mendenhall/Royer approach $^{235}$ as consistent with the state constitution. Under the Mendenhall/Royer approach, a seizure occurs when a reasonable person in the defendant's shoes would have concluded that s/he was

230. In Gray, the court stated:

[A] comparison of the Minnesota Bill of Rights with the federal constitutional provisions upon which the right of privacy is founded shows that the rights protected by the Federal Constitution are also protected by the Minnesota Bill of Rights. Accordingly, it is our opinion that there does exist a right of privacy guaranteed under and protected by the Minnesota Bill of Rights.

Gray, 413 N.W.2d at 111 . The court went on to state that the scope of this right extends only to fundamental rights. See id.

For a comprehensive history of privacy rights under the Minnesota Constitution, see Michael K. Steenson, Fundamental Rights in the "Gray" Area: The Right of Privacy Under the Minnesota Constitution, 20 WM. MITCHELL L. REV. 383 (1994).

231. The court anchored its right to privacy in its state Bill of Rights one year later in Jarvis v. Levine, 418 N.W.2d 139 (Minn. 1987). Mr. Jarvis was a mental patient committed against his will. See id. at 140-41. He successfully challenged the forcible administration of neuroleptic drugs to him in non-emergency situations. See id. at 148. The state supreme court held that the forcible administration of the drugs violated his privacy rights anchored in article I, sections 1,2 , and 10 of the state constitution. See id. at 148. The court stated that "[a]lthough judicial recognition of a constitutional right of privacy in Minnesota may be relatively recent, the protection of bodily integrity has been rooted firmly in our law for centuries." Id. at 148-49.

232. 502 N.W.2d 779 (Minn. 1993).

233. 499 U.S. 621 (1991).

234. See E.D.J., 502 N.W.2d at 781. In Hodari, the Court held that under the Fourth Amendment, "[a]n arrest requires either force (as described above) or, where that is absent, submission to the assertion of authority." Hodari, 499 U.S. at 626.

235. See Florida v. Royer, 460 U.S. 491 (1983); United States v. Mendenhall, 446 U.S. 544 (1980). 
not free to leave and walk away from the police in such a situation. ${ }^{236}$ E.D.J. was a juvenile who was standing with two adults on a known drug-trafficking street corner. ${ }^{237}$ As a police car approached, the three began walking in the opposite direction. The vehicle stopped behind them, and the officers ordered them to stop walking. ${ }^{238}$ As the two men stopped, E.D.J. kept walking, dropped something, and eventually turned around. E.D.J. was later arrested for possession of crack cocaine obtained from a search and seizure. ${ }^{239}$ The state supreme court reversed E.D.J.'s district court conviction and refused to adopt the Hodari approach. ${ }^{240}$ Instead of applying the pre-Hodari, Mendenhall/Royer approach articulated above, the court "exercis[ed its] independent authority to interpret [its] own state constitution ...."241 As a result, the court held that E.D.J. was seized by the police and that the stop was illegal because the police were unable to articulate a sufficient basis for the stop. ${ }^{242}$

One of the most frequently cited cases for an individual liberties protection argument under the Minnesota Constitution is State v. Hershberger. ${ }^{243}$ In Hershberger, the Supreme Court of Minnesota held that a Minnesota Statute requiring the use of a Slow Moving Vehicles ("SMV") sticker on Amish buggies violated article I, section 16 of the Minnesota Constitution. ${ }^{244}$ In addition to declaring that the enumerated rights of the constitution were not all inclusive, ${ }^{245}$ the court noted that section 16 provided highly detailed freedom of religion protections. ${ }^{246}$ The Amish had stated

236. See E.D.J., 502 N.W.2d at 782 (setting forth the Minnesota Supreme Court's full articulation of the Mendenhall/Royer standard).

237. See id. at 780.

238. See id.

239. See id.

240. See id. at 783.

241. E.D.J., 502 N.W.2d at 783.

242. See id.

243. 462 N.W.2d 393 (Minn. 1990).

244. See id. at 399.

245. See id. at 398 (citing State v. Fuller, 374 N.W.2d 722, 726 (1985)).

246. See id. The entire text of article I, section 16 provides:

Freedom of Conscience; no preference to be given to any religious establishment or mode of worship.

The enumeration of rights in this constitution shall not deny or impair others retained by and inherent in the people. The right of every man to worship God according to the dictates of his own conscience shall never be infringed; nor shall any man be compelled to attend, erect or support any place of worship, or to maintain any religious or ecclesiastical ministry, against his consent; nor shall 
that their religious beliefs forbade the use of such symbols. ${ }^{247}$ Realizing that the proposed use of the sticker was for safety purposes, it was suggested that the Amish use reflective tape and red lanterns which would not violate their religious tenets. ${ }^{248}$ The Minnesota Supreme Court agreed and held that the Amish could use the tape and lanterns instead of the SMV stickers. However, on certiorari to the United States Supreme Court, the case was remanded to the state high court for a determination under the compelling state interest/least restrictive means test. ${ }^{249}$

On remand, the Minnesota Supreme Court held that the state statute violated this test. ${ }^{250}$ While public safety had to be served, the court believed that, under the Minnesota Constitution, public safety could be balanced with religious freedom to produce a result that would satisfy both. "Thus, while the terms 'compelling state interest' and 'least restrictive alternative' are creatures of federal doctrine, concepts embodied therein can provide guidance as we seek to strike a balance under the Minnesota Constitution between freedom of conscience and the state's public safety interest."251 The court went on to recognize that religious freedoms have traditionally been treated with high respect by the court. ${ }^{252}$ In deference to this history, and in light of the fact that the state never proved that white reflective tape and red lanterns were inadequate safety precautions, the court held that the law violated the state constitution. ${ }^{253}$

Furthermore, there exists no explicit right in the Minnesota Constitution to grant criminal defendants the right to consult with an attorney before submitting to an intoxilizer test, but the Minnesota Supreme Court granted this right in Freidman $v$.

any control of or interference with the rights of conscience be permitted, or any preference be given by law to any religious establishment or mode of worship; but the liberty of conscience hereby secured shall not be so construed as to excuse acts of licentiousness or justify practices inconsistent with the peace or safety of the state, nor shall any money be drawn from the treasury for the benefit of any religious societies or theological seminaries.

MINN. CONST. art. I, $\S 16$.

247. See Hershberger, 462 N.W.2d at 395.

248. See id. at 399.

249. See Minnesota v. Hershberger, 495 U.S. 910 (1990).

250. See Hershberger, 462 N.W.2d at 399.

251. Id. at 398.

252. See id.

253. See id. at 399. 
Commissioner of Public Safety. ${ }^{254}$ The court has also held that the Minnesota Constitution requires juries of twelve in all criminal cases. ${ }^{255}$ Although the United States Supreme Court had held that juries of less than twelve are allowed in certain non-capital criminal offenses, the Minnesota Supreme Court held that the intent of the framers of the state constitution was to require twelve jurors even in misdemeanor and gross misdemeanor cases. ${ }^{256}$ In granting this right, the court held that it "must remain independently responsible for safeguarding the rights of our own citizens and for insuring that the intent of the people of Minnesota in adopting our constitution is continued forward."257

Hershberger, Fuller, Gray, E.D.J., Friedman, Hamm, and Jarvis all form a strong basis upon which a claim for a teenagers' right to assemble at the Mall of America can be established. As has been shown, Minnesota began a trend towards basing individual liberties protections in its state constitution with Thiede. ${ }^{258}$ The Mall of America situation is unique in that, unlike the other cases herein discussed, this situation could only occur in Minnesota. That this situation is uniquely Minnesotan in nature and ought to be determined under Minnesota law can be most forcibly argued under Jarvis v. Levine. ${ }^{259}$ Deciding a mental patient's right under the Minnesota Constitution to refuse the administration of neuroleptic drugs in nonemergency situations, the Minnesota Supreme Court held that "[w]e are faced with the rights of persons committed to Minnesota institutions, pursuant to Minnesota law, by the courts of this state. Given the significant state law issues involved, we feel it is imperative to assume our obligation to be 'independently responsible for safeguarding the rights of [our] citizens." "260

This reasoning is most persuasive in the Mall of America situation as there is only one Mall of America, and Minnesota is in

254. 473 N.W.2d 828, 837 (Minn. 1991).

255. See State v. Hamm, 423 N.W.2d 379 (Minn. 1988).

256. See id. at 381 (citing Williams v. Florida, 399 U.S. 78 (1970)). The Minnesota Supreme Court focused on the fact that article I, section 6 of the state constitution states that "[i]n all criminal prosecutions the accused shall enjoy the right to a speedy and public trial by an impartial jury ...." MINN. CONST. art. I, $\$ 6$. Additionally, article I, section 4 guarantees that "[t]he right of trial by jury shall remain inviolate ...." Id. § 4 .

257. Hamm, 423 N.W.2d at 382.

258. Thiede v. Town of Scandia Valley, 14 N.W.2d 400, 405 (Minn. 1944).

259. 418 N.W.2d 139 (Minn. 1988). See also supra note 231 and accompanying text.

260. Id. at 147 (quoting State v. Gray, 413 N.W.2d 107, 111 (Minn. 1987)). 
the unique position of being home to what is undoubtedly the world's most famous shopping mall. Thus, while other states have malls that are facing problems with rowdy teenagers, ${ }^{261}$ the Mall of America, while not the first to implement a juvenile curfew, ${ }^{262}$ is the largest and most well-known of the country's malls to have done so. Only the Mall of America has two to three thousand teenagers arriving at its doors on weekends nights, and only the Mall of America has the funds and manpower to deal with the situation on this scale. ${ }^{263}$ Finding a teen right of assembly at the Mall would have a lasting effect on both teenagers' rights and rights of assembly in Minnesota. It would also serve as persuasive authority to other states in which mall managements are considering implementing such a curfew. The Mall of America is so wellknown and there is such widespread interest in it that when it imposed the curfew, the decision was deemed newsworthy enough to be written about in national newspapers across the country. ${ }^{264}$ Surely a decision striking down the curfew as unconstitutional would receive similar coverage and, thus, other mall managements would be aware of it.

In order to make a constitutional argument for teenagers' freedom of assembly rights at the Mall, the Minnesota Supreme Court must ground such a right in the Minnesota Constitution. As has been shown in Gray and its progeny, the court is willing to extend individual liberties protections to those not enumerated in the constitution under article I, section $16{ }^{265}$ Safeguarding the rights of Minnesota citizens by assessing their evolving needs can best be effectuated by granting an affirmative right to freedom of

261. Teresa McFarland states that she has taken calls from malls across the country asking her how the Mall of America deals with unsupervised youth. See Taylor, supra note 172. See also Kokmen, supra note 7; Mall Execs Veto Curfews, LONG IsLand BUS. News, Oct. 28, 1996, at 24; Peterson, supra note 27 (discussing teen problems at local malls as well as the reticence on the part of the mall owners and lack of need to impose a curfew); Vick, supra note 167.

262. See supra note 19 and accompanying text.

263. See Meredith, supra note 7. The Mall's revenue was $\$ 675$ million in 1994 alone. See It's a Megamall World, supra note 128. Some of these monies could have been used to hire more guards and install metal detectors. These are relatively simple safety precautions which could easily be put in place and might obviate the need for the juvenile curfew.

264. For example, when the Mall announced that it was considering a juvenile curfew, the news made the front page of The New York Times and was written about in The Washington Post and The Chicago Tribune, arguably three of the most respected newspapers in the United States. See supra notes 7, 27 and accompanying text.

265. See supra notes $229-32$ and accompanying text. 
assembly at privately owned shopping malls that serve as public downtowns. The court will do well to recognize the Mall of America as a public arena and, as such, a place where First Amendment-type freedoms should not to be denied. Once such a right is grounded in the Minnesota Constitution, then the question becomes whether the state's purpose can be achieved by using any less intrusive methods.

\section{B. Statutory Basis-The Minnesota Human Rights Act}

As has been mentioned, there are many methods by which the Mall of America's Parental Escort Policy can be challenged. While this comment focuses mainly on the constitutional challenge to freedom of assembly rights, other approaches may achieve greater success. One of the alternative arguments, based on the Minnesota Human Rights Act (the "Act"), is briefly discussed because it adds a statutory basis to the constitutional and caselaw analysis discussed above.

The Act was most recently revised by the Minnesota Legislature in $1980 .^{266}$ The provision most applicable to the Mall situation is section 363.03(3) which deals with public accommodations. Section 363.03(3) provides that it is "unfair discriminatory practice: (1) to deny any person the full and equal enjoyment of the goods, services, facilities, privileges, advantages, and accommodations of a place of public accommodation because of race, color, creed, religion, disability, national origin, marital status, sexual orientation, or sex ...."267 In the definitional section of the Act, a place of public accommodation is defined as "a business, accommodation, refreshment, entertainment, recreation, or transportation facility of any kind, whether licensed or not, whose goods, services, facilities, privileges, advantages or accommodations are extended, offered, sold, or otherwise made available to the public."268 Clearly, the Mall of America satisfies the Act's definition of a place of public accommodation. With 520 stores and numerous restaurants, clubs, entertainment facilities, and even a hotel, the Mall qualifies as such a place. Additionally, its goods are extended, offered, and sold to the public at large.

266. See Minn. Stat. AnN. $\$ \S 363.01-20$ (West 1991) (Minnesota Human Rights Act).

267. Id. $\$ 363.03(3)(\mathrm{a})(1)$.

268. Id. § 363.01(33) (1991). 
Once held that the Mall of America is a place of public accommodation under the Minnesota Human Rights Act, it must be determined whether the Mall's Parental Escort Policy falls within the scope of the public accommodations provision. On its face, it appears that it does not. The provision mentions nothing about age. The Parental Escort Policy, serving as a curfew at the Mall of America, is based solely on an age requirement. ${ }^{269}$ In order for the Minnesota Supreme Court to apply the Act to the Parental Escort Policy, the court would have to determine that the list enumerated in the Act is not exclusive. To take such action is not beyond the bounds of the state supreme court's authority. Indeed, as has been shown, the Minnesota Supreme Court has a tradition of granting individual liberty protections not enumerated in the state constitution. Furthermore, the Act itself states that "[t]he provisions of this chapter shall be construed liberally for the accomplishment of the purposes thereof." 270 The main purpose of the Act is "to secure for persons in this state, freedom from discrimination." 271

In one of the first cases in which a cause of action was brought under the Minnesota Human Rights Act, the supreme court, in United States v. McClure, ${ }^{272}$ discussed the long history of the Minnesota anti-discrimination laws and the place they hold for the people of the state. In 1897, 1905, 1943, 1965, and 1980, the Minnesota Legislature showed a continued commitment to fighting discrimination by revising and broadening its anti-discrimination law. ${ }^{273}$ As the court recognized, Minnesota's first anti-discrimination law in 1885 preceded the anything-but "separate but equal" Jim Crow laws and was much more egalitarian than those laws. ${ }^{274}$ The court then found that the United States Jaycees served as a place of public accommodation and, as such, could not continue granting unequal membership privileges to its male and female

269. An action against the Mall of America for racial discrimination is a strong claim under the Act. See infra note 279 and accompanying text.

270. MinN. STAT. ANN. § 363.11 .

271. Id.. \& 363.12.

272. 305 N.W.2d 764 (Minn. 1981). Based on the Minnesota Human Rights Act, the court held that the Jaycees served as a place of public accommodation. See id. at 774. Therefore, based on the Act's nondiscrimination provision relating to sex, the court held that the organization could not grant fewer membership privileges to its female members than those granted to its male members. See id.

273. See id. at 765-68.

274. See id. at 766-67. 
members. ${ }^{275}$ The court engaged in an in-depth analysis of whether the Jaycees, a national organization, served as a place of public accommodation. ${ }^{276}$ Using criteria from other jurisdictions, the court determined that the Jaycees, a nonselective group with an uncapped membership, did serve as a place of public accommodation. ${ }^{277}$

The same logic should be applied to the Mall of America's curfew. The court should construe the statute liberally to consider age as a factor under the Act. Due solely to the teenagers' age, they are denied certain access to the Mall of America. The Minnesota Supreme Court in United States Jaycees noted that Minnesota's human rights laws have grown more inclusive with each revision. ${ }^{278}$ An argument can and should be made for realizing the intent behind this legislation by expanding the Act's protections to include age discrimination. An analysis into the Minnesota Supreme Court's interpretations of legislative acts, be those interpretations strictly literal or broad in scope, would be necessary in making this argument. Such analysis is beyond the scope of this comment, but it is hoped that this comment succeeds in laying the foundation for the myriad constitutional and statutory challenges that may be brought against the Parental Escort Policy. ${ }^{279}$

275. See id. at 774 .

276. See id. at 768-72.

277. See United States Jaycees, 305 N.W.2d at 768-72.

278. See id. at 765-68.

279. Indeed, this comment is narrow in scope compared to the number of approaches that can be taken in challenging the curfew. Again, the focus of this comment is to lay the foundation in arguing for an individual liberty right of teenager assembly under the Minnesota Constitution. However, there are numerous ways of challenging the validity of the juvenile curfew. Following is a very brief overview of three alternative arguments for challenging the Mall of America's Parental Escort Policy.

First, one of the strongest arguments which can be made is that the Parental Escort Policy discriminates against black youth who only frequent the Mall in such large numbers on weekend evenings. See Apgar, supra note 186; Meredith, supra note 7. While Mall management has stated that it implemented the curfew as a colorblind measure, the effect of the curfew undeniably affects black youth in greater numbers. See id. (noting President of the Minneapolis Urban League, Gary Sudduth's outcry upon the curfew's implementation). Under the Federal Constitution, a discriminatory motive, and not just a discriminatory effect, must be found in order for the cause of action to succeed. See Mayor of Washington, D.C. v. Davis, 426 U.S. 229 (1976). However, such a finding is not necessary under all state laws. Hence, it would be worth studying further the Minnesota Human Rights Act and state caselaw to determine whether a discriminatory motive must be present or whether a discriminatory impact is sufficient for a finding of discrimination. If the curfew is found to be discriminatory, as the evidence indicates, the next question is whether the stated nondiscriminatory intent is sufficient to sustain it in light of the discriminatory impact or whether 


\section{Alternatives}

\section{After the New Jersey Supreme Court in New Jersey Coalition} had granted petitioners the right to leaflet at the defendants' malls, the court stated:

There is concern, understandable concern, about the possibility of confrontation, disturbance, and even violence-concerns not just for business, but for the safety and security of people at the premises. Freedom of speech has always had this potential, controversy being part of its nature. Defendants' fears are not fanciful, but this is hardly a novel problem. This country, and its cities, and more to the point, its downtown business districts, have successfully dealt with it and lived with it for centuries. ${ }^{280}$

The court stated that the speech right granted-that of distributing leaflets-was not likely to result in harm to the

the curfew is a pretext for discrimination.

Secondly, a due process argument under the Minnesota Constitution Rights and Privileges Clause, should be explored. See MINN. ConST. art. I, $\S 2$. The first sentence of that provision states that "[n]o member of this state shall be disfranchised or deprived of any of the rights or privileges secured to any citizen thereof, unless by the law of the land or the judgment of his peers." Id.

In conjuction with a Minnesota due process claim, an argument may be made under the state curfew regulations. Minnesota has a curfew regulation establishing that "a county board may adopt an ordinance establishing a countywide curfew for unmarried persons under 18 years of age ...." MINN. STAT. ANN. § 145A.05(7)(2) (West Supp. 1997). An argument may be made analogizing the Mall of America's Parental Escort Policy to municipal curfews across the country. A number of the curfews have been invalidated due to the broadness of their scope. By contrast, many of the curfews that have been upheld are more narrowly tailored. An analogy can be made to the Mall of America situation by arguing that its curfew is overboard and that the result desired by Mall management can be achieved with more narrowly tailored means. See discussion infra Part V.

Third, a federal Fourteenth Amendment due process argument can also be raised in conjunction with this state argument. See U.S. CONST. amend. XIV, $\S 1$. Under the Federal Constitution, teens are not granted equal rights as compared to adults. See Bellotti v. Baird, 443 U.S. 622 (1979), reh'g denied, 444 U.S. 887 (1979). However, in a number of state cases challenging local municipal juvenile curfew laws under both state and federal law, state courts have been closely divided on whether juvenile curfews deny teens assembly and association rights. Depending on whether the state court viewed teen assembly rights as fundamental or as somewhat less, the courts used either heightened scrutiny or the rational basis test to determine the constitutionality of a municipal curfew. See In re J.M., 768 P.2d 219 (Colo. 1989); Deerfield v. Greenberg, 550 N.E.2d 12 (IIl. App. Ct. 1990); People v. Chambers, 360 N.E.2d 55 (Ill. 1976); City of Maquoketa v. Russell, 484 N.W.2d 179 (Iowa 1992); Brown v. Ashton, 660 A.2d 447 (Md. Ct. Spec. App. 1992); Bykofsky v. Middletown, 401 F. Supp. 1242 (M.D. Pa. 1975), cert. denied, 429 U.S. 964 (1976).

280. New Jersey Coalition Against War in the Middle East v. J.M.B. Realty Corp., 650 A.2d 757, 782 (N.J. 1994). 
shopping centers or to the people inside them because that right was "the least intrusive form of free speech and the easiest to control."281 The right this comment advocates, that of teen assembly, is arguably higher up on the "intrusiveness" scale. There is a justified concern about future violence in the Mall of America; however, there are practical alternatives to the juvenile curfew and very strong public policy reasons why the Mall should use them before turning to the Parental Escort Policy. The alternatives, discussed herein, are less intrusive than the Parental Escort Policy and may perhaps be even more effective in preserving the Mall as a safe environment for all who enter. The two most prominent public policy reasons for repealing the Parental Escort Policy are: (1) to repair relations with the black community, and (2) to repair relations with teen shoppers in general, a group with great spending power and which has been alienated by the Mall's policy.

The first and most important reason for the Mall to reconsider its policy is to regain the trust of the black community. Even before the juvenile escort policy was implemented, members of the black community believed that the Mall discriminated against lowincome black youth. ${ }^{282}$ These allegations were based on arguments that Mall security discriminately handed-out the Mall's Conduct Code more often to black youth as compared to white youth; additionally, security allegedly approached more groups of black teens than white teens. ${ }^{283}$ Mall management has steadfastly

281. Id.

282. See supra note 167 and accompanying text.

Given the Mall's earlier attempt to restrict bus access to its site, we can only conclude that racism is playing a role here .... It seems to us that the Mall of America believes that children of color will not have a parent-or a car-readily available for their visit to the mall. Therefore, they believe, the new policy requiring the presence of a parent will reduce the number of non-white young people in the mall in the early evening.

Apgar, supra note 186 (quoting Gary Sudduth, President of the Minneapolis Urban League). See also Taylor, supra note 172 (stating that "[t]he mall has been getting criticism from members of the African-American community, who claim black youths are unduly harassed [by mall security]").

There have been at least two discrimination suits filed by African Americans against the Mall of America. First, three women filed a discrimination complaint against the Mall in 1996 after their teenage daughters had a scuffle with Mall security. See Taylor, supra note 172; Margaret Zack, Cop Disciplined for Conduct in Megamall Arrest, MINNEAPOLIS-ST. PAUL STAR-TRIB., May 4, 1996. The suit was settled for $\$ 200,000$. Second, in October 1995 , three different minority teens sued the Mall on their own behalf. See Taylor, supra note 172.

283. See Meredith, supra note 7. The article quotes Marcus Wilson, an 18 year-old black teen who goes to the Mall on weekend nights, who stated that Mall security tend to give him 
held that its security implementation is colorblind, ${ }^{284}$ but the introduction of the curfew, the practical effect of which is to keep large groups of black teens out of the Mall on weekend nights, has not convinced the black community that the curfew was not racially motivated. Indeed, the only time such large numbers of black teens go to the Mall is on weekend nights. ${ }^{285}$

It can and should be argued that the Mall has a responsibility to the community with which it has a symbiotic relationship. The community has given the Mall its business while the Mall has provided the surrounding area with thousands of jobs. ${ }^{286}$ With the Mall's prominence in the Bloomington/Minneapolis community comes a responsibility to treat all those in the community with respect. Even before it had opened the Mall had gained national prominence, and the implementation of the Parental Escort Policy was national news. ${ }^{287}$ By its very existence, the Mall of America has become the preeminent mall in America. With that reputation comes the responsibility of being a role model. It may not be a role the Mall management desired, but it has become the Mall's role nonetheless. ${ }^{288}$ With the concern voiced by the Minneapolis Urban Coalition and the Urban League, the Mall would show its continuing commitment to social problems by recognizing the race issue and by effecting another policy that would not have such a disproportionate effect on the area's black youth. By implementing an alternative to the curfew that is more egalitarian in nature, the Mall would best effectuate this commitment and set an example which would be seen by the rest of the country.

The second reason for the Mall to rescind its Parental Escort Policy flows somewhat from the first. Malls across the country are watching the Mall of America's juvenile curfew to discern whether

a copy of the Conduct Code when he enters the mall; by contrast, white teenagers are rarely handed copies of the Code. See id.

284. See McFarland Interview, supra note 16.

285. See Meredith, supra note 7; Telephone Interview with Yusef Mgeni, President of the Urban Coalition in the Twin Cities (Sept. 25, 1996).

286. The Mall of America employs approximately 12,000 people. See AT A GLANCE, supra note 1.

287. See supra notes 7,27 and accompanying text.

288. Famous people and places, such as the Mall of America, are closely watched by the media and the country at large. This should make them aware that their actions (or inaction) are observed and that they have the tremendous power of setting as good an example as a poor one. 
such a policy is effective. ${ }^{289}$ The Mall would set an example as to the treatment of all teenagers were it to end its policy of welcoming them on weekend evenings only with a parental escort. As one commentator has noted, the curfew might solve the Mall's problems, but it also "might unnecessarily damage its relationship with teens and reinforce negative stereotypes of them." 290 Teens do not have as many rights as adults do in this country, but the Mall would set an example as to how to treat teens with greater respect were it to institute an alternative to the curfew that would achieve similar results as the curfew. The best way to ask teens to act like responsible adults may be to treat them in a more adultlike fashion. ${ }^{291}$

This objective could perhaps be best effectuated if the Mall began using the state Unlawful Assembly and Disorderly Conduct statutes at its disposal. ${ }^{292}$ Rather than denying access to a whole class of people, the vast majority of whom are innocent of any wrongdoing, the Mall should deny access to the few who display poor conduct. The Mall could replace the information about the Parental Escort Policy on the Conduct Code handout with a warning that state statutes will be used to keep violators off the premises. The statutes alone can in fact be used to keep perpetrators out of the Mall. As has hopefully been proven in this comment, the behavior of the majority of the teens is consistent with Mall policy. As the New Jersey Supreme Court in New Jersey

289. See supra notes 27,261 and accompanying text.

290. Teen Curfews-Paterson Should Think Twice Before Acting, THE RECORD (Bergen County, N.J.), Sept. 12, 1996.

291. With the Parental Escort Policy, the Mall of America has effectively alienated many members of the teen population. While Mall management argues that most of the teens who go to the Mall on weekend nights do not go there for shopping, teens in general have a tremendous amount of spending power in this country. Were other malls across the country to follow the Mall of America's example, they could find themselves effectively closing off a large source of revenue. According to Teenage Research Unlimited, teenage spending in the United States is estimated at over $\$ 100$ billion annually. See Kokmen, supra note 7 . In the same article, Mark Schoifet, Spokesman for the International Council of Shopping Centers, states that "nobody in our industry wants to alienate this group ... . They grow into adults, and they are the people you want as your loyal customers. Ninety nine point nine percent of kids are good kids . . . . But sometimes dealing with teenagers is a difficult dilemma for mall managers." Id.

292. See MinN. STAT. ANN. \& 609.705 (West 1987) (Unlawful Assembly); see also id. $\S 609.72$ (West Supp. 1997) (Disorderly Conduct). Under the disorderly conduct statute, one is guilty of disorderly conduct if one "engages in offensive, obscene, abusive, boisterous, or noisy conduct or in offensive, obscene, or abusive language tending reasonably to arouse alarm, anger, or resentment in others." Id. 
Coalition states, simply "hanging around" the Mall is allowed. ${ }^{293}$ It is only those who are violent who should not be allowed in the Mall. ${ }^{294}$ The Mall would set an example that violent and disruptive behavior is not tolerated by having the offending teens arrested. Therefore, the violent teens, and the teens who congregate in large groups which act as a public nuisance, would be on notice that their behavior will not be tolerated by the Mall or by society. The latter group, which is the more prevalent group at the Mall, should not be banned. Rather, it is those groups that are especially large in number or loud in their behavior who should be asked to split up into smaller, less obtrusive groups. The failure to do so would result in arrest. While this sounds like a harsh remedy for teens who are only gathered in large groups, after such a remedy is imposed once, it is not likely to be necessary again. Using state statutes to police the Mall would perhaps be the most effective method of keeping violent teens out of the Mall while at the same time informing others that such behavior will not be condoned.

The Mall has repeatedly conceded that most of the kids who go to the Mall on weekend nights are good kids. ${ }^{295}$ A safe environment need not be achieved at the expense of denying the well-behaved teens access to the Mall; this is the practical effect of the Parental Escort Policy. Nor will keeping the well-behaved teens from the Mall serve to make the Mall a safer environment. If safety is the Mall's objective, an effort should be made to at all times restrict permanent Mall access to the teenagers who have exhibited violent behavior on Mall premises. A violent incident may occur at 5 p.m. on a Saturday or perhaps 1 p.m. on a Wednesday when teenagers are on school vacation. Banning violent teens from the Mall altogether will have the lasting effect of making the Mall safer at all times rather than only on weekend evenings. Implementing this policy would require distributing pictures and names of violators to Mall security and instructing Mall security to deny access to those teens. Security should also be authorized to arrest as a trespasser any teen gaining access to the Mall who has been a perpetrator of a violent incident at the Mall. While this approach may seem difficult in practice, Mall security now requests

293. See New Jersey Coalition Against War in the Middle East v. J.M.B. Realty Corp., 650 A.2d 757, 773 (N.J. 1994).

294. The issue of prior restraint, while pertinent to this topic, is beyond the scope of this comment.

295. See supra notes $192-96$ and accompanying text. 
identification of all people thought to be under the age of sixteen. To request identification of those individuals thought to be perpetrators of Mall violence is far less intrusive than asking every teen for identification. ${ }^{296}$

Indeed, perhaps the most egalitarian method of insuring Mall safety would be the installation of metal detectors at each Mall entrance. This would have the effect of not only banning teens with weapons, but it would keep all persons with weapons out of the Mall. While this measure may sound harsh, suggestive of airport metal detectors and dangerous inner-city schools, metal detectors will do the best job of keeping all concealed weapons off Mall premises. If Mall patrons are concerned about their safety, they should tolerate the minor inconvenience of removing their keys and passing through the detector. The effect of using metal detectors would be to keep all weapons out of the Mall and not just those that teenagers carry. If a seventeen year-old were to bring a gun to the Mall, the teen would be denied entrance under this policy. Conversely, under the Parental Escort Policy, entrance would be granted once identification proving age over sixteen was shown.

Lastly, hiring more Mall security and strictly enforcing the Conduct Code would in all likelihood alleviate the problem of teen violence. ${ }^{297}$ At least one other mall has found success by strictly enforcing its conduct code and ejecting violators for anywhere from thirty days to one year from mall premises. ${ }^{298}$ Granted, no other mall can compare in size to the Mall of America, but most of the teens at the Mall of America do not pose a safety threat. As Mall spokeswoman Teresa McFarland herself has said, the majority of teens at the Mall are well-behaved, and it is the minority who spoil it for the majority. ${ }^{299}$

296. See supra note 291 and accompanying text. This editorial compares the Mall of America curfew with a proposed teen curfew in Paterson, New Jersey and suggests that both the Mall of America and Paterson can achieve their goals without imposing curfews. See id. The editorial recommends banning the teens who cause problems, rather than asking for identification from every teen attempting to enter the Mall. See id.

297. This alternative would be most effective if implemented in conjunction with other alternatives previously discussed.

298. See Peterson, supra note 27 (quoting David Groom, General Manager of the Monmouth Mall in Eatontown, New Jersey).

299. See supra note 192 and accompanying text. 
Mall security already has an active community component in place with the Youth Liaison Program. ${ }^{300}$ The Mighty Moms and Dedicated Dads also serve as an effective link to the community because the moms and dads live in the same areas as many of the teens. However, the Mall could do more within the community before implementing the curfew. One step should be working with community centers and perhaps religious organizations in order to provide alternatives to going to the Mall on weekend nights. Indeed, one reason so many teens go to the Mall of America may be that they have nowhere else to go in the Bloomington/Minneapolis area on weekend nights. The Mall could take the initiative to work with local groups to plan alternate, safe events for teenagers. As many of the teens go to the Mall on weekend nights only to be with one another, it is likely that they would be interested in another place that provided a space to relax with friends, especially one where they could comfortably hang-out in large groups. Since such a venue would welcome large groups of teens, this could become an attractive alternative for many Minnesota teens. Community centers and religious houses could offer their spaces on a rotating basis. Perhaps for a minimum entrance fee special events, such as a dance or a comedy night, would be offered.

\section{Affirmative Defenses}

The strongest argument to be made by the Mall of America on behalf of the Parental Escort Policy is that the policy works to promote a safe environment. ${ }^{301}$ The number of arrests at the Mall has decreased dramatically. ${ }^{302}$ Once the Mall is determined to serve as a downtown area such that its actions constitute state action, the Mall will likely defend the policy by stating that the policy is in the best interests for the health, safety, and welfare of

300. See supra note 9 and accompanying text.

301. After the first weekend that the Parental Escort Policy was put into effect, Mall management stated that " $[t]$ he policy is working exactly as we intended. More families came out to enjoy the mall and it was a safer atmosphere for everyone. This was the first weekend in memory where we didn't have a fight between kids." October Press Release, supra note 184.

302. From January through October 1996, 394 arrests were made at the Mall. From the time the Juvenile Curfew Policy went into effect through June 1997, there has been only one arrest. See Gupta, supra note 198. 
Minnesota citizens. While the Mall should be concerned about safety, the fact that a safety interest is involved is not dispositive of the constitutionality of the action. As the Minnesota Supreme Court stated in Hershberger, "[m]erely because public safety is articulated as a competing interest in section 16 , however, does not establish that interest as paramount." ${ }^{303}$ In relation to the Mall of America, once the court determines that the curfew is state action, the question then becomes whether the state's interest in protecting the safety of its citizens at the Mall can be achieved in an equally effective method that is less violative of individual rights. The author of this comment is fully aware that teen assembly rights have not traditionally been of equal constitutional concern as freedom of religious expression, ${ }^{304}$ search and seizure rights, ${ }^{305}$ or the bodily integrity of the mentally ill. ${ }^{306}$ While stretching the bounds of constitutional concern, this comment argues that the Minnesota courts can and should draw on their rich history of caselaw to require less restrictive alternatives before a right so fundamental as freedom of assembly is infringed. As best evidenced by Hershberger, as well as by E.D.J. and Jarvis, Minnesota places a high premium on individual liberties. The court would hopefully consider the previously discussed alternatives to the curfew and hold that the Mall's safety objective could be effectuated in such a way that would serve the goal of keeping the Mall safe for all its patrons without the need to resort to a Parental Escort Policy.

After the safety argument, the Mall's second line of defense may rely on article I, section 13 of the Minnesota Constitution which provides that "[p]rivate property shall not be taken, destroyed or damaged for public use without just compensation therefor, first paid or secured."307 The United States Supreme Court addressed this argument in PruneYard, holding that the rights of free expression and petition did not amount to an unconstitutional taking under the Fifth Amendment Takings Clause. $^{308}$ The court stated that " $[\mathrm{t}]$ here is nothing to suggest that

303. State v. Hershberger 462 N.W.2d 393, 399 (Minn. 1990).

304. See id. at 393-400.

305. See In re Welfare of E.D.J., 502 N.W.2d 779 (Minn. 1993).

306. See Jarvis v. Levine, 418 N.W.2d 139 (Minn. 1988).

307. MINN. CONST. art. I, § 13.

308. See PruneYard Shopping Ctr. v. Robins, 447 U.S. 74, 83 (1980). See also U.S. CONST. amend. $\mathrm{V}$. 
preventing appellants from prohibiting this sort of activity will unreasonably impair the value or use of their property as a shopping center." ${ }^{309}$ Indeed, the Mall of America did not state that the few gun-related incidents had in any way diminished the Mall's revenue. Thus, it cannot be argued that the implementation of the curfew has restored lost business to the Mall. The Mall stated that it had received complaints from shoppers that they found the large groups of teens to be intimidating, but again, the Mall had no statistics indicating that business was down due to the congregating teens. The Mall has not argued that it has lost business or revenue on account of the teenagers' actions, and this line of argument would in all likelihood fail when compared to the great benefit the Mall has obtained by making itself so accessible to the general public. ${ }^{310}$

\section{Conclusion}

As one individual has said: "[N]o place can shut out the depressing realities of our new, uncivil society. If the promise of the Mall of America was to seal off the tumult of the outside world, that is a promise no enterprise can likely keep."311

A balance must be struck between respecting the Mall of America's need to maintain a safe environment and teenagers' right of assembly in the Mall. Mall of America's management has made many efforts to curb teen violence and teen congregating on Mall premises. Mall management has shown a commitment to dealing with this situation; however, further steps could and should have been taken before the Mall instituted its Parental Escort Policy. The policy is too broad in its scope and keeps out the many good teens in order to deny access to the few who misbehave. Under the Minnesota Constitution, a strong argument can be made for

309. PruneYard, 447 U.S. at 83.

310. A counterpart to the takings argument is that the Mall, as private property, has a right to exclude. An analysis of this argument is beyond the scope of this comment. However, it is worth noting that while the Mall does have a right to exclude in order to make its premises safer, it can achieve this goal by excluding only those teens who are violent and violate the Conduct Code, which is a class much narrower than those now affected under the Parental Escort Policy.

311. Greene, supra note 10. 
recognizing teenagers' assembly rights at the Mall of America. It is intended that this comment serve as a starting point for bringing such a constitutional challenge.

Alysa B. Freeman 